\title{
Impacts of emission reduction and meteorological conditions on air quality improvement during the 2014 Youth Olympic Games in Nanjing, China
}

\author{
Qian Huang ${ }^{1,2}$, Tijian Wang ${ }^{1}$, Pulong Chen ${ }^{1}$, Xiaoxian Huang ${ }^{3}$, Jialei Zhu ${ }^{4}$, and Bingliang Zhuang ${ }^{1}$ \\ ${ }^{1}$ School of Atmospheric Sciences, CMA-NJU Joint Laboratory for Climate Prediction Studies, \\ Jiangsu Collaborative Innovation Center for Climate Change, Nanjing University, Nanjing, 210023, China \\ ${ }^{2}$ Scientific Research Academy of Guangxi Environmental Protection, Nanning, 530022, China \\ ${ }^{3}$ College of Plant Science \& Technology, Huazhong Agricultural University, Wuhan, 430070, China \\ ${ }^{4}$ Department of Climate and Space Sciences and Engineering, University of Michigan, Ann Arbor, 48109, USA
}

Correspondence to: Tijian Wang (tjwang@nju.edu.cn)

Received: 6 February 2017 - Discussion started: 1 March 2017

Revised: 7 September 2017 - Accepted: 22 September 2017 - Published: 13 November 2017

\begin{abstract}
As the holding city of the 2nd Youth Olympic Games (YOG), Nanjing is highly industrialized and urbanized, and faces several air pollution issues. In order to ensure better air quality during the event, the local government took great efforts to control the emissions from pollutant sources. However, air quality can still be affected by synoptic weather, not only emission. In this paper, the influences of meteorological factors and emission reductions were investigated using observational data and numerical simulations with WRF-CMAQ (Weather Research and Forecasting - Community Multiscale Air Quality). During the month in which the YOG were held (August 2014), the observed hourly mean concentrations of $\mathrm{SO}_{2}, \mathrm{NO}_{2}, \mathrm{PM}_{10}, \mathrm{PM}_{2.5}, \mathrm{CO}$ and $\mathrm{O}_{3}$ were $11.6 \mu \mathrm{g} \mathrm{m}^{-3}, 34.0 \mu \mathrm{g} \mathrm{m}^{-3}, 57.8 \mu \mathrm{g} \mathrm{m}^{-3}, 39.4 \mu_{\mathrm{g} \mathrm{m}}{ }^{-3}$, $0.9 \mathrm{mg} \mathrm{m}^{-3}$ and $38.8 \mu \mathrm{g} \mathrm{m}^{-3}$, respectively, which were below China National Ambient Air Quality Standard (level 2). However, model simulation showed that the weather conditions, such as weaker winds during the YOG, were adverse for better air quality and could increase $\mathrm{SO}_{2}, \mathrm{NO}_{2}, \mathrm{PM}_{10}$, $\mathrm{PM}_{2.5}$ and $\mathrm{CO}$ by $17.5,16.9,18.5,18.8,7.8$ and $0.8 \%$. Taking account of local emission abatement only, the simulated $\mathrm{SO}_{2}, \mathrm{NO}_{2}, \mathrm{PM}_{10}, \mathrm{PM}_{2.5}$ and $\mathrm{CO}$ decreased by 24.6, 12.1, $15.1,8.1$ and $7.2 \%$. Consequently, stringent emission control measures can reduce the concentrations of air pollutants in the short term, and emission reduction is very important for air quality improvement during the YOG. A good example has been set for air quality protection for important social events.
\end{abstract}

\section{Introduction}

Located in the economically developed Yangtze River Delta (YRD) region of China, Nanjing successfully hosted the second Youth Olympic Games (YOG) during 16-28 August 2014. Nanjing is a highly urbanized city and its GDP ranked 12th of all the cities in China in 2013. Due to fast urbanization and industrialization, heavy motor vehicles and construction dust, Nanjing has long suffered from air pollution (Dong et al., 2013; Chen et al., 2015).

In order to realize the promise of a "Green YOG", the local government took a series of measures to reduce emissions of air pollutants. The preparatory work started from 1 July 2014. The local government carried out the plan for stringent environmental quality assurance from 1 August. The controlled emissions include five major categories: industry, power plants, traffic, VOC product-related sources and others. Some local petrochemical, chemical and steel industries were forced to limit or halt production. Coal-combustion enterprises were required to use high-quality coals with low sulfur content and ash content. Vehicles with heavy pollution called "yellow label buses" were prohibited in Nanjing during 10-28 August. Oil loading and unloading operations were strictly controlled. All construction processes in the city were forced to stop.

It is well known that air quality can be affected by both meteorological factors and pollutant emissions. Many cases have verified that both emission abatement and weather con- 
ditions can influence the improvement of local air quality. Emissions have been controlled during many social events, for example in the Beijing Olympic Games in 2008 and Shanghai Expo in 2010. Xing et al. (2011) suggested that the control of emissions is beneficial for pollutant reduction, but meteorological effects can go either way at different locations. Cermak and Knutti (2009), W. T. Wang et al. (2009), Wang et al. (2010) and Xing et al. (2011) reported that typical meteorological conditions accounted more for air improvement during the 2008 Beijing Olympics than emission reductions. Zhou et al. (2010) concluded that control measures for transportation resulted in reductions of 44.5 and $49.0 \%$ in daily $\mathrm{CO}$ and $\mathrm{NO}_{x}$ emission from motor vehicles during the 2008 Olympics. Cai and Xie (2011) and $X$. Wang et al. (2009) also studied the transportation controls that were enforced to improve air quality during the Beijing Olympic Games. Okuda et al. (2011) argued that controlling sources during the Beijing Olympics significantly reduced $\mathrm{PM}_{10}, \mathrm{NO}_{2}$ and $\mathrm{SO}_{2}$ but did not effectively reduce $\mathrm{PM}_{2.5}$. Streets et al. (2007) proposed that controlling local sources is inadequate for a heavily populated, urbanized and industrialized city - regional air quality management is in urgent need. Lin et al. (2013) applied monitoring data to analyse the weather impacts on air quality of the World Expo in the YRD and concluded that the high frequency of marine winds during the Expo had a positive effect on the air quality of coastal cities but a negative effect on some inland cities in the YRD. Satellite data reflected that the tropospheric $\mathrm{NO}_{2}$ column, aerosol optical thickness (AOT), and CO concentrations dropped by 8,14 and $12 \%$ over Shanghai during the Expo period, compared to the past 3 years (Hao et al., 2011). Liu et al. (2013) compared the contributions of long-term and short-term emission controls via CMAQ (Community Multiscale Air Quality) simulation and investigated their effects on air quality in Guangzhou during the Asian Games. Xu et al. (2013) concluded that $\mathrm{PM}_{2.5}$ was mainly emitted from anthropogenic sources other than biogenic sources and indicated that cutting anthropogenic emissions could decrease $\mathrm{PM}_{2.5}$ effectively. Dong et al. (2013) found that independent $\mathrm{NO}_{x}$ emission reduction would strengthen $\mathrm{O}_{3}$ as a side effect in the YRD. Chen et al. $(2015,2017)$ studied the source apportionment of size-fractionated particles in Nanjing and found that fugitive and construction dust decreased significantly in YOG.

There have been some studies on air quality during the 2nd YOG (Ding et al., 2015; Chen et al., 2017; Zhou et al., 2017), but few studies focused on the relative contributions of meteorology and control efforts. This study takes the air quality monitoring data and applies the WRF-CMAQ (Weather Research and Forecasting - Community Multiscale Air Quality) model to estimate the effect of meteorological factors and emission reduction on the air quality of Nanjing during the 2nd YOG. Data and model descriptions as well as simulation scenarios are described in Sect. 2. Section 3 examines the characteristics of six major air pollutants $\left(\mathrm{SO}_{2}, \mathrm{NO}_{2}, \mathrm{PM}_{10}\right.$,
$\mathrm{PM}_{2.5}, \mathrm{CO}$ and $\mathrm{O}_{3}$ ) and compares their concentrations during the YOG with those from a year ago (August 2013) and the months without emission reduction (July and September 2014). In addition, this section discusses the separate effect of weather conditions and emission abatement qualitatively and quantitatively based on the simulation results. Section 4 summaries the main conclusions, emphasizes the importance of the air quality measures during the YOG and provides some advice for ensuring pleasant air quality in future.

\section{Methodology}

\subsection{Data description}

Hourly observed air quality data during July-September 2014 and August 2013 of two representative stations were collected from Nanjing Environmental Monitoring Center (http://222.190.111.117:8023/). Both stations are statecontrolled air-monitoring sites. The data quality assurance and quality control procedures for monitoring strictly follow the national standards (State Environmental Protection Administration of China, 2006). Caochangmen (CCM) station $\left(118.75^{\circ} \mathrm{E}, 32.06^{\circ} \mathrm{N}\right)$ is located in Gulou District, the city centre of Nanjing. Gulou District is the centre of economy, politics, culture and education in Nanjing, where many of eastern China's high-end industrial and corporate headquarters are located. Over $90 \%$ provincial authorities, more than 20 colleges and universities, and more than 120 institutes are situated in Gulou District. It is the most populated area in Nanjing, with a lively commercial hub and heavy traffic. Thus, CCM station was chosen to represent the urban status of Nanjing. The other site is called Xianlin (XL) station $\left(118.92^{\circ} \mathrm{E}, 32.11^{\circ} \mathrm{N}\right)$, which is located in Qixia District, the suburb of Nanjing. Compared to Gulou District, Qixia District is much more sparsely populated with few traffic congestion problems. Thus, XL station was chosen to represent suburban Nanjing.

\subsection{Model description}

The integrated modelling system WRF-CMAQ was employed in this study. Community Multiscale Air Quality (CMAQ) is a third-generation regional air quality model developed by the Environmental Protection Agency of USA (USEPA). It incorporates a set of up-to-date compatible modules and control equations for the atmosphere and can fully consider complicated physical and chemical processes (Byun and Schere, 2006; Foley et al., 2010). Many applications have proven that CMAQ is a reliable tool for simulating air quality from city scale to mesoscale (Xing et al., 2011; Dong et al., 2013; Liu et al., 2013; Xu et al., 2013; Shu et al., 2016). The Community Multiscale Air Quality (CMAQ v4.7.1, Binkowski and Roselle, 2003) model includes the 2005 Carbon Bond gas-phase mechanism (CB05) (Yarwood et al., 2005) and the fourth-generation CMAQ 
(a)

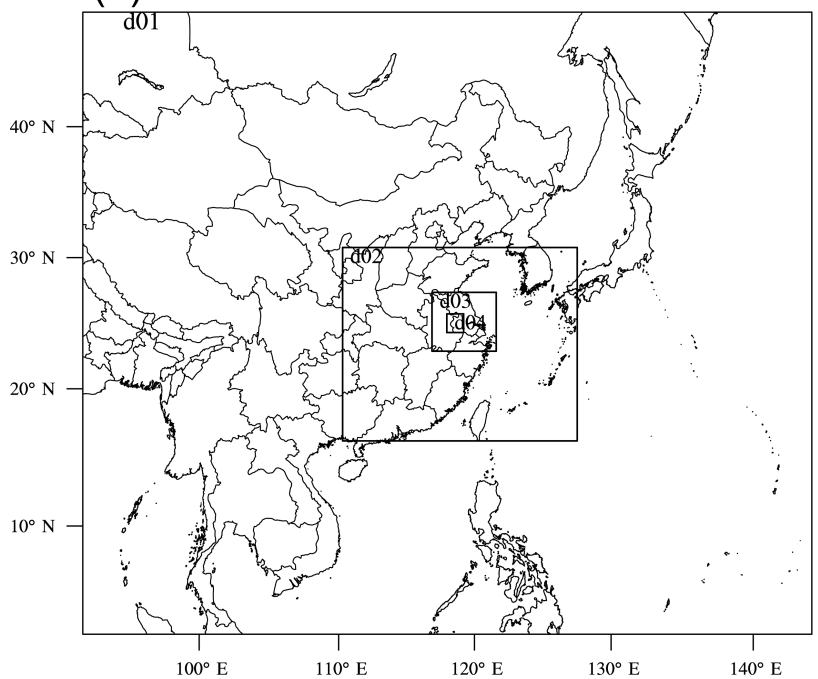

(b)

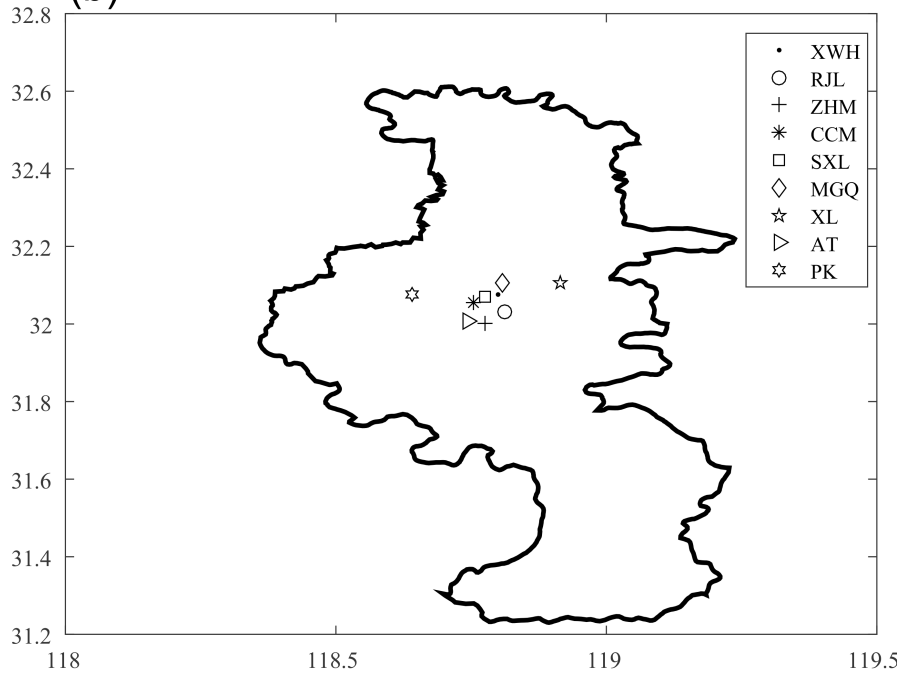

Figure 1. Modelling domains and state-controlled air-monitoring sites in Nanjing. (a) The four nested modelling domains at $81 \mathrm{~km}$ (d01: eastern Asia), 27 km (d02: eastern China), 9 km (d03: Yangtze River Delta), and 3 km (d04: Nanjing), (b) locations of nine sites in Nanjing.

aerosol module (AERO4) (Byun and Schere, 2006). It was applied to simulate the pollutant distribution over Nanjing in this study. Weather Research and Forecasting (WRF) is a new generation of mesoscale weather forecast model and assimilation system, developed by the National Center for Atmospheric Research (NCAR). It has been widely applied in China and shows a good performance in all kinds of weather forecasts (Jiang et al., 2008, 2012; Xu et al.,2013; Liao et al., 2014, 2015; Xie et al., 2014, 2016; Li et al., 2016; Shu et al., 2016). The WRF v3.2.1 (Skamarock et al., 2008) model was run to provide meteorological fields for CMAQ. Four nested domains were set for both models, with horizontal resolutions of 81, 27, 9 and $3 \mathrm{~km}$, and the innermost domain covering Nanjing (Fig. 1). For all domains, 23 vertical sigma layers from the surface to the top pressure of $100 \mathrm{hpa}$ were set, with about 10 layers in the planetary boundary layer. The detailed dynamic parameterization in WRF as well as the physical and chemical schemes of CMAQ applied in this research were the same as those in Shu et al. (2016)'s work and were proven to have good performance. As for the innermost domain, Nanjing Environmental Protection Bureau chooses the local nine state-controlled air-monitoring sites (see Fig. 1, Table 1) to represent the whole of Nanjing (NJ) city. To conform to this, the nine sites in domain 4 were chosen to represent the whole of Nanjing when analysing the impacts of weather conditions and emission reduction.

\subsection{Emissions and simulation scenarios}

In this study, Multi-resolution Emission Inventory for China (MEIC v1.2, http://www.meicmodel.org/dataset-meic.html), with a resolution of $0.25^{\circ} \times 0.25^{\circ}$, was employed to provide the anthropogenic emissions for species including $\mathrm{SO}_{2}, \mathrm{NO}_{x}$,
Table 1. The air-monitoring sites in Nanjing.

\begin{tabular}{lll}
\hline Site & Abbreviation & Location \\
\hline Xuanwuhu station & XWH & $32.08^{\circ} \mathrm{N}, 118.80^{\circ} \mathrm{E}$ \\
Ruijinlu station & RJL & $32.03^{\circ} \mathrm{N}, 118.82^{\circ} \mathrm{E}$ \\
Zhonghuamen station & $\mathrm{ZHM}$ & $32.00^{\circ} \mathrm{N}, 118.76^{\circ} \mathrm{E}$ \\
Caochangmen station & $\mathrm{CCM}$ & $32.06^{\circ} \mathrm{N}, 118.75^{\circ} \mathrm{E}$ \\
Shanxilu station & $\mathrm{SXL}$ & $32.07^{\circ} \mathrm{N}, 118.77^{\circ} \mathrm{E}$ \\
Maigaoqiao station & $\mathrm{MGQ}$ & $32.11^{\circ} \mathrm{N}, 118.81^{\circ} \mathrm{E}$ \\
Xianlin station & $\mathrm{XL}$ & $32.11^{\circ} \mathrm{N}, 118.92^{\circ} \mathrm{E}$ \\
Aoti station & AT & $32.01^{\circ} \mathrm{N}, 118.74^{\circ} \mathrm{E}$ \\
Pukou station & PK & $32.07^{\circ} \mathrm{N}, 118.64^{\circ} \mathrm{E}$ \\
\hline
\end{tabular}

CO, NMVOC, $\mathrm{NH}_{3}, \mathrm{CO}_{2}, \mathrm{PM}_{2.5}, \mathrm{PM}_{10}$, $\mathrm{BC}$ and $\mathrm{OC}$, which form four sectors: industry, power plants, transportation and residential.

For the innermost domain, the local emission inventory was used before and after emission control with a horizontal resolution of $3 \mathrm{~km} \times 3 \mathrm{~km}$. The base year of the local emission is 2012. According to the local emission control programme, five major categories - industry, power plants, traffic, VOC product-related sources and others - were in the control list. In August 2014, all coal-combustion enterprises must use high-quality coals with sulfur content less than $0.5 \%$ and ash content less than $13 \%$. In addition, the local government ordered over 100 local petrochemical, chemical and steel enterprises to cut or halt their production. Moreover, heavy pollution vehicles were prohibited in Nanjing during 10-28 August 2014 to reduce traffic emission. To reduce emissions of volatile organic compounds, loading and unloading oil operations were prohibited at the docks in the Nanjing section of Yangtze River. Furthermore, local con- 
(a) $\mathrm{SO}_{2}$

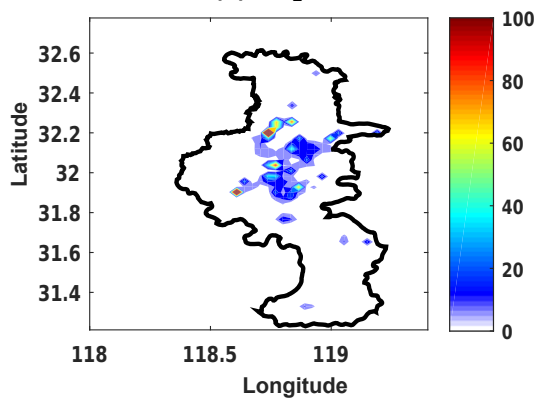

(b) $\mathrm{NO}_{x}$

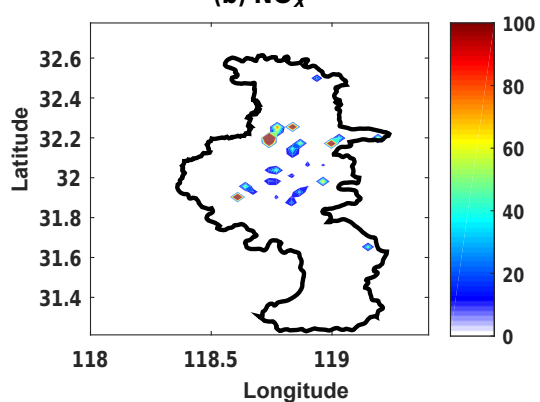

(c) $\mathrm{PM}_{10}$

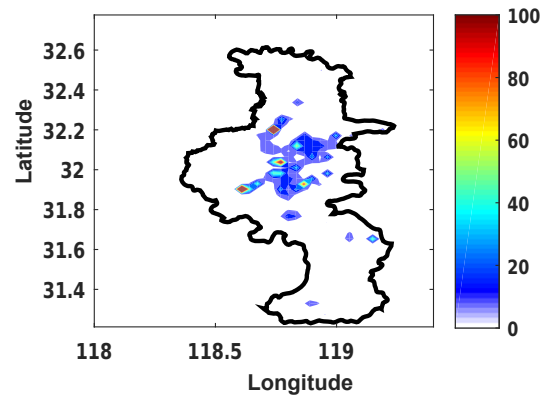

(d) $\mathbf{P M}_{2.5}$

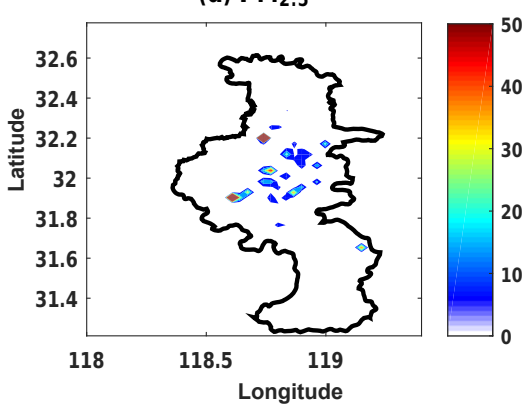

(e) CO

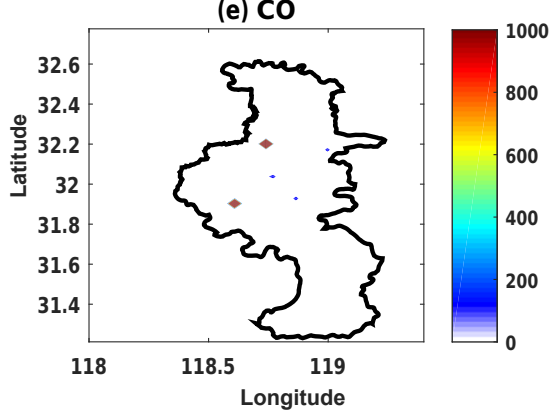

Figure 2. Emission reduction in domain 4. (a) $\mathrm{SO}_{2}$, (b) $\mathrm{NO}_{X}$, (c) $\mathrm{PM}_{10}$, (d) $\mathrm{PM}_{2.5}$, (e) $\mathrm{CO}\left(\mathrm{t} \mathrm{month}^{-1}\right.$ ).

struction work was halted during August 2014. With these efforts, the emission would be cut by $25.0 \%$ for $\mathrm{SO}_{2}, 15.0 \%$ for $\mathrm{NO}_{x}, 42.8 \%$ for $\mathrm{PM}_{10}, 36.2 \%$ for $\mathrm{PM}_{2.5}$ and $20.0 \%$ for $\mathrm{CO}$. The spatial distributions of emission reduction for different species were shown in Fig. 2. $\mathrm{SO}_{2}, \mathrm{NO}_{x}, \mathrm{PM}_{10}$ and $\mathrm{PM}_{2.5}$ were centred in the middle of Nanjing city and $\mathrm{CO}$ was centred around several points.

The simulated period was from 27 July to 1 September (China Standard Time, CST), but only the month in which the YOG were held (1 August to 31 August) was focused on for discussion. In order to better understand the influence of meteorological factors and emission abatement, three experiments were carried out. Experiment 1 used the weather conditions during August 2014 (CST) and the emission inventory after reduction. Experiment 2 used the same weather conditions as Experiment 1 with the emission inventory before reduction. Experiment 3 used the same inventory as Experiment 2 and the weather conditions during August 2013 (CST). Experiment 2 acted as the control experiment. Therefore, Experiment 1 and Experiment 2 were performed to investigate the influence of emission reduction on pollutant levels. Similarly, Experiment 2 and Experiment 3 were conducted to understand the impact of meteorology on air quality.

\section{Results and discussions}

\subsection{Observed air quality during the YOG}

In August 2014, emission sources from five major categories were strictly reduced, and the air quality was greatly improved compared to August 2013. Firstly, air quality was good during the games in accordance with China's National Ambient Air Quality Standards (NAAQS) (Figs. 3, 4). The hourly mean concentrations of pollutants at the two sites during August 2014 are $11.6 \mu \mathrm{g} \mathrm{m}^{-3}$ for $\mathrm{SO}_{2}, 34.0 \mu \mathrm{g} \mathrm{m}^{-3}$ for $\mathrm{NO}_{2}, 57.8 \mu \mathrm{g} \mathrm{m}^{-3}$ for $\mathrm{PM}_{10}, 39.4 \mu \mathrm{g} \mathrm{m}^{-3}$ for $\mathrm{PM}_{2.5}$, $0.9 \mathrm{mg} \mathrm{m}^{-3}$ for $\mathrm{CO}$ and $38.8 \mu \mathrm{g} \mathrm{m}^{-3}$ for $\mathrm{O}_{3}$. Secondly, as shown in Tables 2 and 3, the mean concentrations of the six major species dropped by $64.7 \%$ for $\mathrm{SO}_{2}, 29.8 \%$ for $\mathrm{PM}_{10}, 9.8 \%$ for $\mathrm{PM}_{2.5}, 8.9 \%$ for $\mathrm{CO}$ and $31.7 \%$ for $\mathrm{O}_{3}$ at CCM station, and by $50.0 \%$ for $\mathrm{SO}_{2}, 18.6 \%$ for $\mathrm{NO}_{2}$, $32.8 \%$ for $\mathrm{PM}_{10}, 4.1 \%$ for $\mathrm{PM}_{2.5}$ and $31.7 \%$ for $\mathrm{O}_{3}$ at $\mathrm{XL}$ station. The smaller standard deviations (SD) of $\mathrm{SO}_{2}, \mathrm{NO}_{2}$, $\mathrm{CO}$ and $\mathrm{O}_{3}$ revealed that concentrations of these air pollutants varied more steadily in August 2014. In fact, the drop of pollutant concentrations could be caused mainly by meteorological conditions or emission reduction, which will be discussed based on model simulations in Sect. 3.2 and 3.3.

Analogously, when comparing the observational data in August 2014 with those in July and September 2014 (the months before and after the most aggressive abatement), the concentrations of most species also clearly decreased. As presented in Figs. 5 and 6, without abatement, $\mathrm{NO}_{2}, \mathrm{PM}_{10}$, $\mathrm{PM}_{2.5}$ and $\mathrm{O}_{3}$ were likely to exceed NAAQS, especially for 
$\mathrm{SO}_{2}$

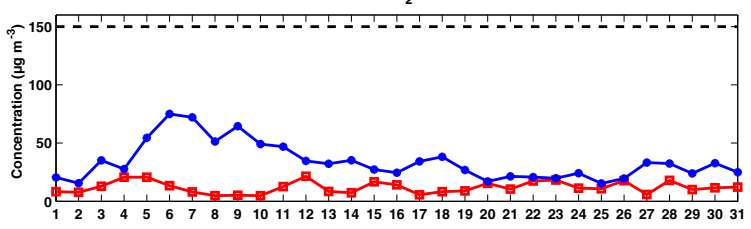

$\mathrm{PM}_{10}$

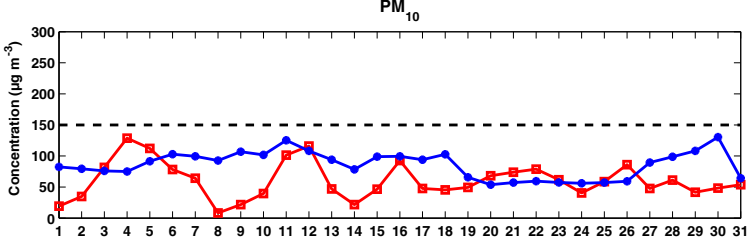

co

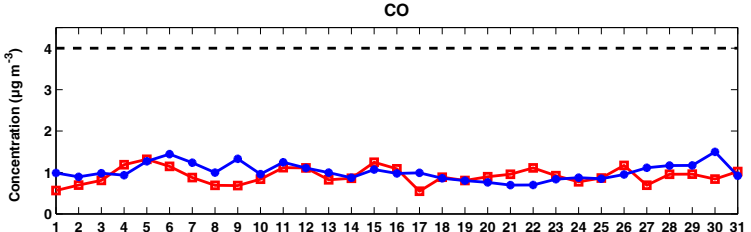

$\mathrm{NO}_{2}$

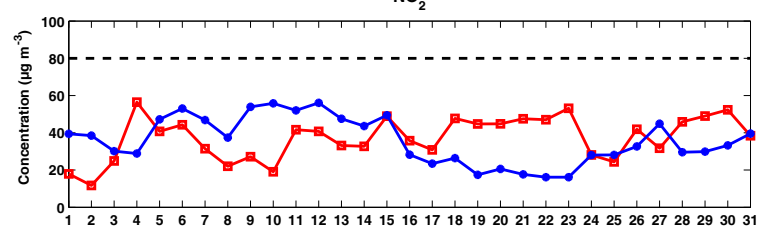

- - Aug. 2013

Figure 3. Day-to-day variations in $\mathrm{SO}_{2}, \mathrm{NO}_{2}, \mathrm{PM}_{10}, \mathrm{PM}_{2.5}, \mathrm{CO}$ and $\mathrm{O}_{3}-8 \mathrm{~h}$ (over an average of $8 \mathrm{~h}$ ) at CCM station in August 2013 and August 2014 (CST). Observed data for August 2013 and August 2014 are indicated in blue and red respectively. NAAQS are indicated with a black dotted line.
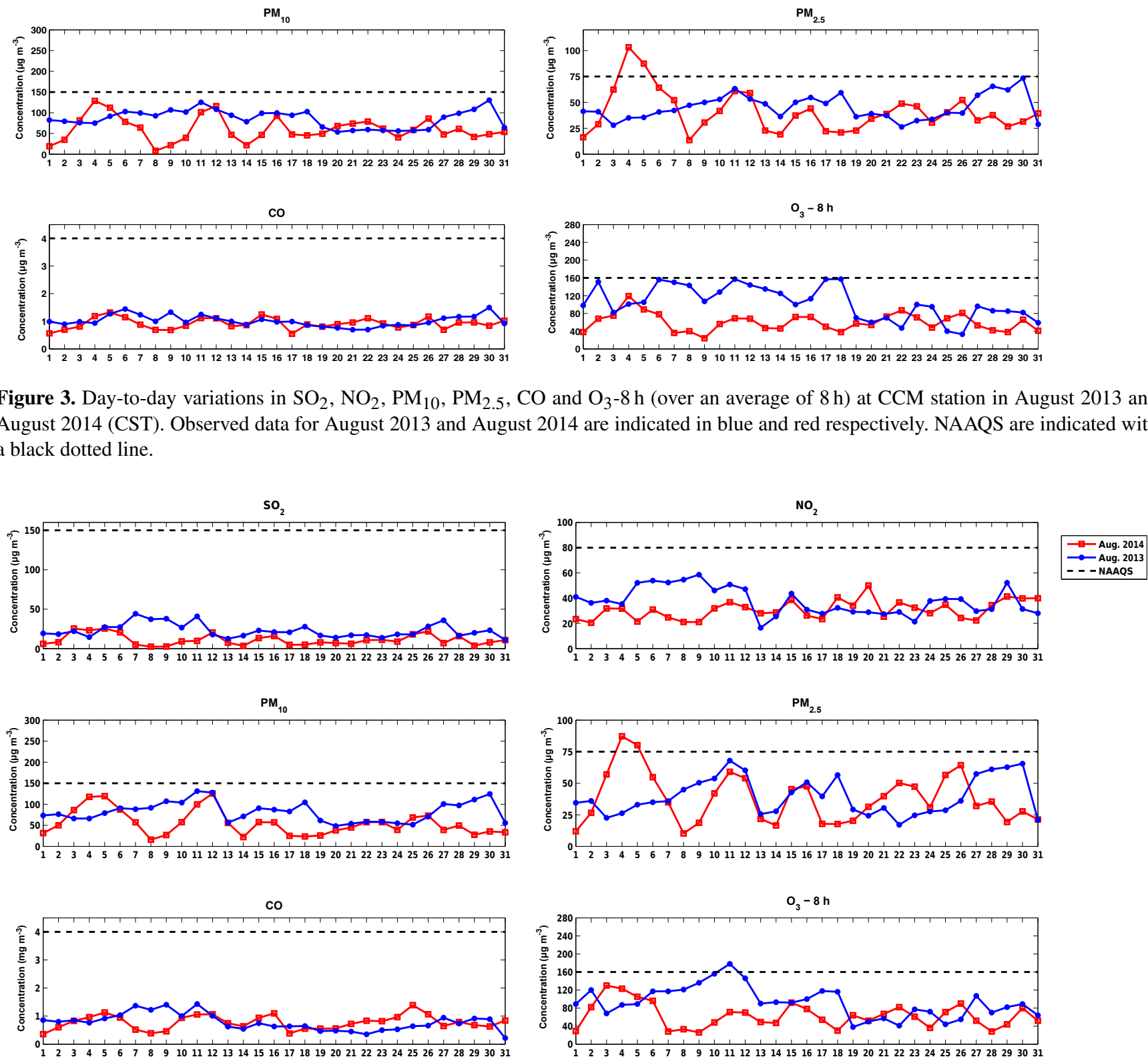

Figure 4. Day-to-day variations in $\mathrm{SO}_{2}, \mathrm{NO}_{2}, \mathrm{PM}_{10}, \mathrm{PM}_{2.5}, \mathrm{CO}$ and $\mathrm{O}_{3}-8 \mathrm{~h}$ at XL station in August 2013 and August 2014 (CST). Observed data for August 2013 and August 2014 are indicated in blue and red respectively. NAAQS are indicated with a black dotted line.

$\mathrm{PM}_{2.5}$ and $\mathrm{O}_{3}$. As shown in Tables 4 and 5, compared with July 2014, the concentrations of $\mathrm{NO}_{2}, \mathrm{PM}_{10}, \mathrm{PM}_{2.5}, \mathrm{CO}$ and $\mathrm{O}_{3}$ dropped by $0.7,31.8,33.7,1.1$ and $52.8 \%$, at CCM station in August 2014, while the concentrations of $\mathrm{SO}_{2}, \mathrm{NO}_{2}$, $\mathrm{PM}_{10}, \mathrm{PM}_{2.5}, \mathrm{CO}$ and $\mathrm{O}_{3}$ decreased by $15.8,39.6,34.6,7.1$ and $50.7 \%$ at XL station in August 2014. Without emission control, the concentration of air pollutants rebounded in September 2014. Compared to August, the concentrations of $\mathrm{SO}_{2}, \mathrm{NO}_{2}, \mathrm{PM}_{10}, \mathrm{PM}_{2.5}$ and $\mathrm{O}_{3}$ increased by 37.4, 19.8, 37.6, 22.3 and 47.2\% at the CCM station in September 
Table 2. Statistical analysis of hourly data in August 2013 and August 2014 at CCM station (the unit is $\mu g \mathrm{~m}^{-3} \mathrm{except} \mathrm{CO} \mathrm{(mg} \mathrm{m}^{-3}$ )). The change percentage of species $(\Delta)$ in August 2014 is based on August 2013.

\begin{tabular}{llrrrrrr}
\hline Species & Time & Max & Min & Mean & Median & SD & $\Delta$ \\
\hline $\mathrm{SO}_{2}$ & August 2013 & 169.0 & 1.0 & 33.7 & 27.0 & 23.7 & \\
& August 2014 & 72.0 & 2.0 & 11.9 & 10.0 & 7.8 & $-64.7 \%$ \\
$\mathrm{NO}_{2}$ & August 2013 & 111.0 & 1.0 & 35.4 & 32.0 & 19.4 & \\
& August 2014 & 110.0 & 1.0 & 37.3 & 35.0 & 18.6 & $5.0 \%$ \\
$\mathrm{PM}_{10}$ & August 2013 & 213.0 & 19.0 & 86.0 & 84.0 & 29.5 & \\
& August 2014 & 198.0 & 6.0 & 60.4 & 54.0 & 36.6 & $-29.8 \%$ \\
$\mathrm{PM}_{2.5}$ & August 2013 & 123.0 & 10.0 & 45.2 & 43.5 & 16.2 & \\
& August 2014 & 165.0 & 3.0 & 40.7 & 36.0 & 23.8 & $-9.8 \%$ \\
$\mathrm{CO}^{*}$ & August 2013 & 3.1 & 0.4 & 1.0 & 0.9 & 0.4 & \\
$\mathrm{O}_{3}$ & August 2014 & 2.2 & 0.3 & 0.9 & 0.9 & 0.3 & $-8.9 \%$ \\
& August 2013 & 198.0 & 1.0 & 56.9 & 42.0 & 46.2 & \\
& August 2014 & 150.0 & 9.0 & 38.9 & 34.0 & 22.6 & $-31.7 \%$ \\
\hline
\end{tabular}

Table 3. Statistical analysis of hourly data in August 2013 and August 2014 at XL station (the unit is $\mu \mathrm{g} \mathrm{m}^{-3} \mathrm{except} \mathrm{CO}\left(\mathrm{mg} \mathrm{m}^{-3}\right.$ )). The change percentage of species $(\Delta)$ in August 2014 is based on August 2013.

\begin{tabular}{llrrrrrr}
\hline Species & Time & Max & Min & Mean & Median & SD & $\Delta$ \\
\hline $\mathrm{SO}_{2}$ & August 2013 & 139.0 & 0.0 & 22.8 & 19.0 & 16.1 & \\
& August 2014 & 71.0 & 1.0 & 11.4 & 8.0 & 10.4 & $-50.0 \%$ \\
$\mathrm{NO}_{2}$ & August 2013 & 129.0 & 0.0 & 37.7 & 32.0 & 21.7 & \\
& August 2014 & 95.0 & 7.0 & 30.7 & 27.0 & 15.0 & $-18.6 \%$ \\
$\mathrm{PM}_{10}$ & August 2013 & 215.0 & 0.0 & 82.1 & 79.0 & 32.4 & \\
& August 2014 & 196.0 & 6.0 & 55.2 & 47.0 & 35.9 & $-32.8 \%$ \\
$\mathrm{PM}_{2.5}$ & August 2013 & 122.0 & 0.0 & 39.7 & 37.5 & 18.9 & \\
$\mathrm{CO}$ & August 2014 & 157.0 & 3.0 & 38.0 & 34.0 & 24.1 & $-4.1 \%$ \\
& August 2013 & 3.2 & 0.0 & 0.8 & 0.7 & 0.4 & \\
$\mathrm{O}_{3}$ & August 2014 & 2.0 & 0.3 & 0.8 & 0.7 & 0.3 & $<0.1 \%$ \\
& August 2013 & 193.0 & 0.0 & 56.6 & 44.0 & 37.5 & \\
& August 2014 & 148.0 & 2.0 & 38.7 & 32.0 & 28.3 & $-31.7 \%$ \\
\hline
\end{tabular}

2014 (Table 4), while the concentrations of $\mathrm{SO}_{2}, \mathrm{NO}_{2}, \mathrm{PM}_{10}$, $\mathrm{PM}_{2.5}, \mathrm{CO}$ and $\mathrm{O}_{3}$ increased by $24.6,21.8,28.7,17.7,4.9$ and $39.9 \%$ at the XL station in September 2014 (Table 5). In addition, for most species, the standard deviation was lowest in August, which meant that the potential for extreme events was lowest in August. Assuming that the weather conditions in July, August and September 2014 were similar, it can be suggested that emission sources have the greatest impact on the concentration changes during the 3 months. These results proved that concentrations of most species decreased and had less potential in extreme events after aggressive emission abatement. However, the concentrations increased without emission control. Section 3.3 further discusses the change of pollutant concentration with and without emission reduction based on model simulation.

\subsection{Simulated impact of meteorological conditions}

In this paper, the model configurations were the same as those set by Shu et al. (2016), who evaluated the model per- formance of WRF-CMAQ and proved the model's reliability in simulating air quality in Nanjing.

As we know, meteorology has a large impact on air quality. Good diffusion conditions can alleviate air pollution in the short term (Cermak and Knutti, 2009; W. T. Wang et al., 2009). Under this premise, if two experiments (Experiment 2 and Experiment 3) use the same emission inventory but different weather conditions, it can be concluded that the higher concentrations may result from poor meteorological conditions. According to model simulation, Experiment 2 exhibited higher pollutant concentrations for all species in most parts of Nanjing as shown in Fig. 7. Concentrations of $\mathrm{SO}_{2}$, $\mathrm{NO}_{2}, \mathrm{PM}_{10}, \mathrm{PM}_{2.5}, \mathrm{CO}$ and $\mathrm{O}_{3}$ increased by $17.5,16.9,18.5$, 18.8, 7.8 and $0.8 \%$ during August 2014 compared to August 2013. Additionally, the contributions of meteorological conditions to primary and secondary particulate matter differed (see Fig. 8). Secondary $\mathrm{PM}_{10}\left(\mathrm{PM}_{10 \mathrm{~s}}\right)$ rose by $21.5 \%$, while primary $\mathrm{PM}_{10}\left(\mathrm{PM}_{10 \mathrm{p}}\right)$ rose by $12.6 \%$ during August 2014 compared to August 2013. Secondary $\mathrm{PM}_{2.5}\left(\mathrm{PM}_{2.5 \mathrm{~s}}\right)$ was increased by $21.5 \%$, while primary $\mathrm{PM}_{2.5}\left(\mathrm{PM}_{2.5 \mathrm{p}}\right)$ 

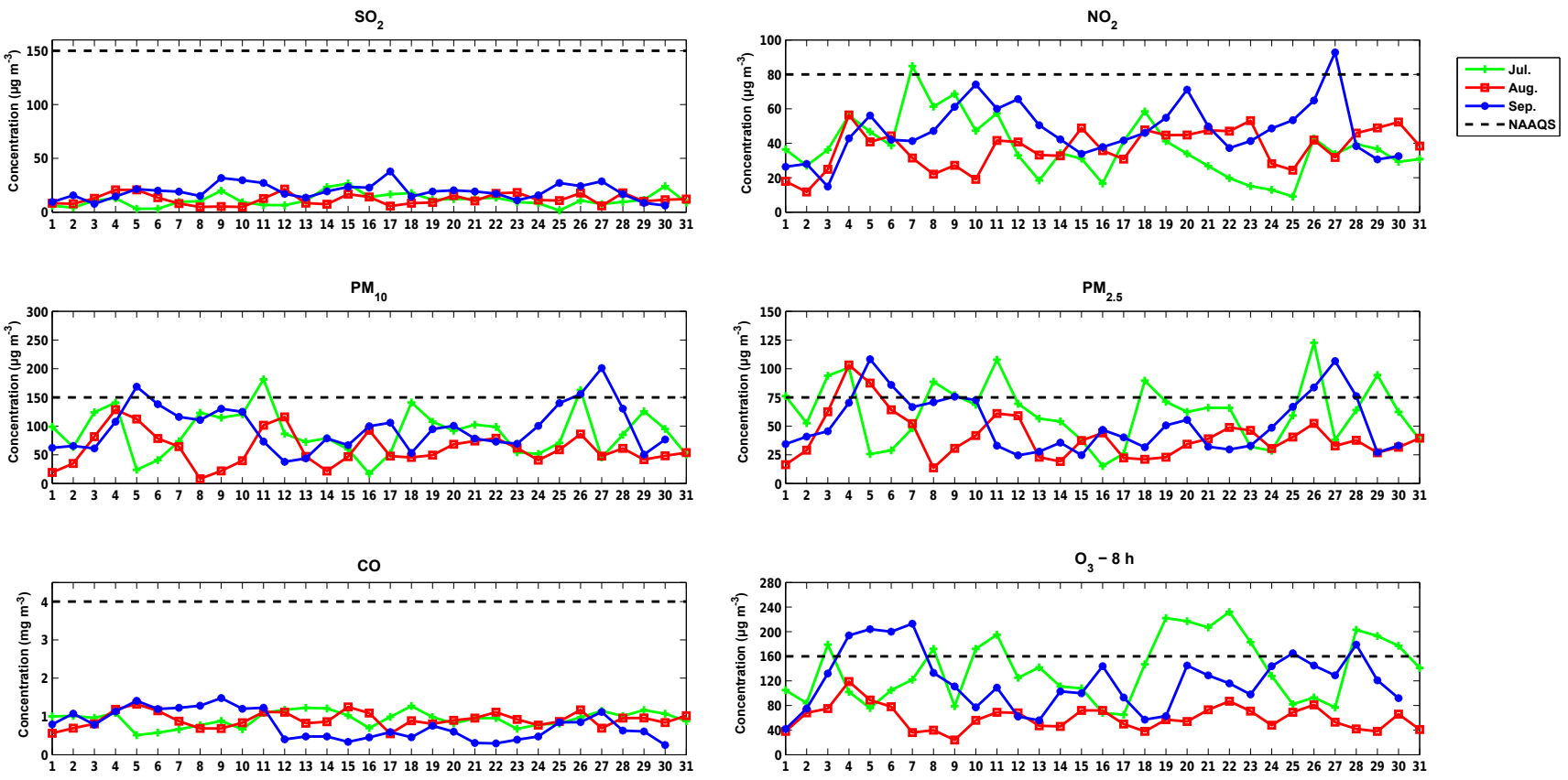

Figure 5. Day-to-day variations in $\mathrm{SO}_{2}, \mathrm{NO}_{2}, \mathrm{PM}_{10}, \mathrm{PM}_{2.5}, \mathrm{CO}$ and $\mathrm{O}_{3}-8 \mathrm{~h}$ at CCM station in July, August and September 2014 (CST). Observed data for July, August and September 2014 are indicated in green, red and blue respectively. NAAQS are indicated with a black dotted line.
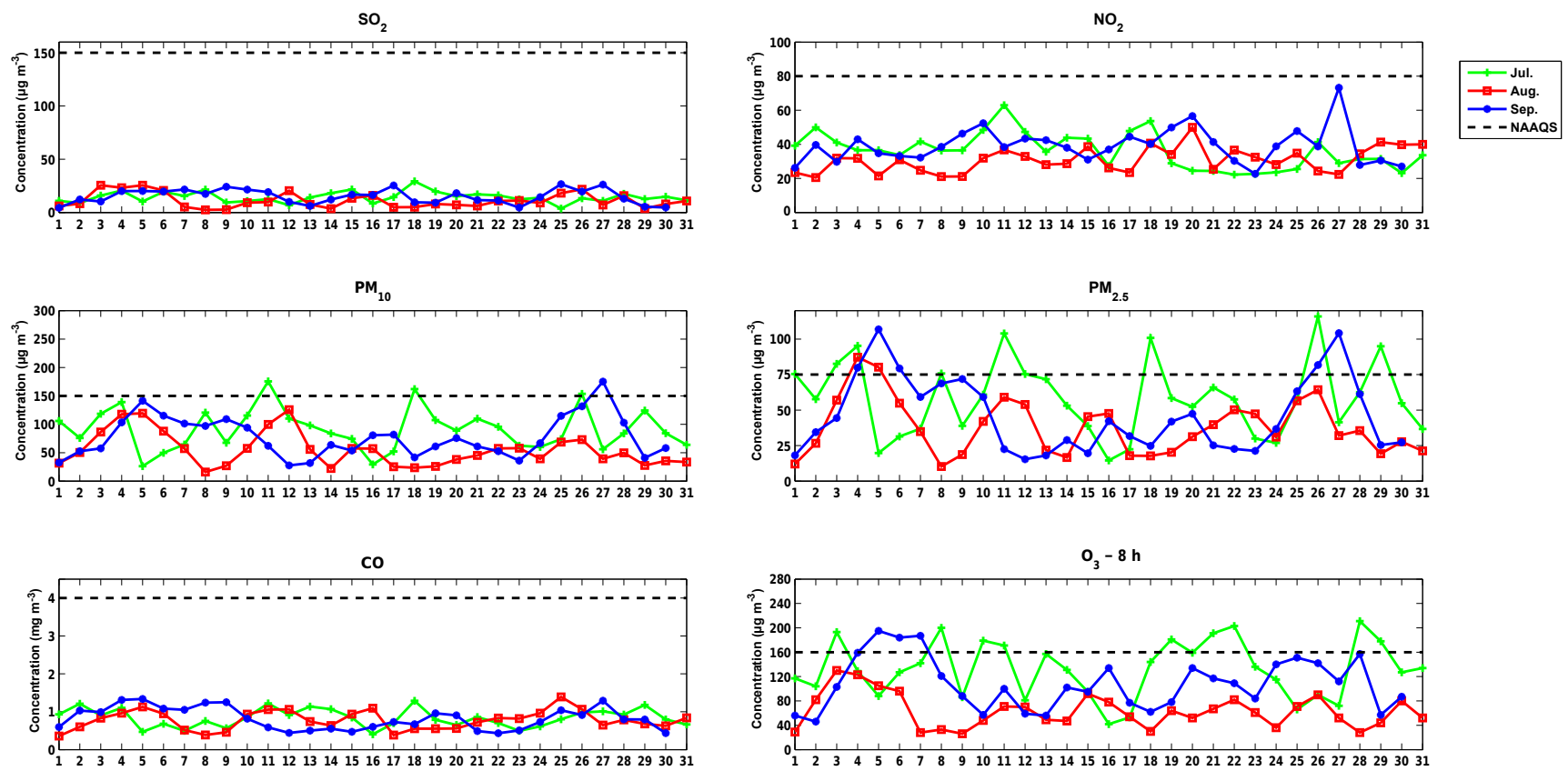

Figure 6. Day-to-day variations in $\mathrm{SO}_{2}, \mathrm{NO}_{2}, \mathrm{PM}_{10}, \mathrm{PM}_{2.5}, \mathrm{CO}$ and $\mathrm{O}_{3}-8 \mathrm{~h}$ at XL station in July, August and September 2014 (CST). Observed data for July, August and September 2014 are indicated in green, red and blue respectively. NAAQS are indicated with a black dotted line.

was enhanced by $9.5 \%$. Thus, the weather conditions had a slightly greater impact on secondary fine particulate matter. Moreover, for $\mathrm{SO}_{2}, \mathrm{NO}_{2}, \mathrm{PM}_{10}, \mathrm{PM}_{2.5}, \mathrm{CO}, \mathrm{PM}_{10 \mathrm{p}}, \mathrm{PM}_{10 \mathrm{~s}}$, $\mathrm{PM}_{2.5 \mathrm{p}}$ and $\mathrm{PM}_{2.5 \mathrm{~s}}$, there were some small decreasing areas in north-eastern Nanjing (Figs. 7 and 8). In domain 4, the simulated predominant wind was north-easterly in August 2014 but south-easterly in August 2013. So, the diffusion 
Table 4. Statistical analysis of hourly data in July-September 2014 at CCM station (the unit is $\mu \mathrm{g} \mathrm{m}^{-3}$ except for CO (mg m $^{-3}$ )). The change percentage of species $(\Delta a)$ in August 2014 is based on July 2014. The change percentage of species $(\Delta b)$ in August 2014 is based on September 2014.

\begin{tabular}{|c|c|c|c|c|c|c|c|c|}
\hline Species & Month & Max & Min & Mean & Median & SD & $\Delta \mathrm{a}$ & $\Delta \mathrm{b}$ \\
\hline \multirow{4}{*}{$\mathrm{SO}_{2}$} & July 2014 & 83.0 & 1.0 & 11.3 & 9.0 & 9.8 & \multirow{4}{*}{$5.1 \%$} & \multirow{4}{*}{$-37.4 \%$} \\
\hline & August 2014 & 72.0 & 2.0 & 11.9 & 10.0 & 7.8 & & \\
\hline & September 2014 & 70.0 & 4.0 & 19.0 & 18.0 & 9.9 & & \\
\hline & July-September 2014 & 83.0 & 1.0 & 14.0 & 12.0 & 9.8 & & \\
\hline \multirow[t]{4}{*}{$\mathrm{NO}_{2}$} & July 2014 & 161.0 & 1.0 & 37.5 & 32.0 & 28.3 & \multirow{4}{*}{$-0.7 \%$} & \multirow{4}{*}{$-19.8 \%$} \\
\hline & August 2014 & 110.0 & 1.0 & 37.3 & 35.0 & 18.6 & & \\
\hline & September 2014 & 151.0 & 8.0 & 46.5 & 42.0 & 24.5 & & \\
\hline & July-September 2014 & 161.0 & 1.0 & 40.2 & 37.0 & 24.4 & & \\
\hline \multirow[t]{4}{*}{$\mathrm{PM}_{10}$} & July 2014 & 255.0 & 6.0 & 88.5 & 88.0 & 50.7 & \multirow{4}{*}{$-31.8 \%$} & \multirow{4}{*}{$-37.6 \%$} \\
\hline & August 2014 & 198.0 & 6.0 & 60.4 & 54.0 & 36.6 & & \\
\hline & September 2014 & 243.0 & 6.0 & 96.7 & 90.0 & 45.8 & & \\
\hline & July-September 2014 & 255.0 & 6.0 & 81.7 & 76.0 & 47.4 & & \\
\hline \multirow[t]{4}{*}{$\mathrm{PM}_{2.5}$} & July 2014 & 171.0 & 1.0 & 61.5 & 58.0 & 33.9 & \multirow{4}{*}{$-33.7 \%$} & \multirow{4}{*}{$-22.3 \%$} \\
\hline & August 2014 & 165.0 & 3.0 & 40.7 & 36.0 & 23.8 & & \\
\hline & September 2014 & 143.0 & 3.0 & 52.4 & 46.0 & 27.2 & & \\
\hline & July-September 2014 & 171.0 & 1.0 & 51.5 & 45.0 & 29.9 & & \\
\hline \multirow[t]{4}{*}{$\mathrm{CO}$} & July 2014 & 2.7 & 0.2 & 0.9 & 0.9 & 0.3 & \multirow{4}{*}{$-1.1 \%$} & \multirow{4}{*}{$21.1 \%$} \\
\hline & August 2014 & 2.2 & 0.3 & 0.9 & 0.9 & 0.3 & & \\
\hline & September 2014 & 2.1 & 0.1 & 0.8 & 0.7 & 0.4 & & \\
\hline & July-September 2014 & 2.7 & 0.1 & 0.9 & 0.8 & 0.4 & & \\
\hline \multirow[t]{4}{*}{$\mathrm{O}_{3}$} & July 2014 & 281.0 & 4.0 & 82.4 & 69.0 & 57.6 & \multirow{4}{*}{$-52.8 \%$} & \multirow{4}{*}{$-47.2 \%$} \\
\hline & August 2014 & 150.0 & 9.0 & 38.9 & 34.0 & 22.6 & & \\
\hline & September 2014 & 240.0 & 6.0 & 73.6 & 61.0 & 49.2 & & \\
\hline & July-September 2014 & 281.0 & 4.0 & 64.7 & 51.0 & 49.3 & & \\
\hline
\end{tabular}

condition of north-eastern Nanjing might be better in August 2014 and resulted in a small decrease in these areas.

The overall increasing pollutant levels in August 2014 suggested that the diffusion conditions in August 2014 were worse than those in August 2013. Focus on the weather conditions during the YOG (16-28 August 2014) and the same period in 2013, the simulated hourly mean $10 \mathrm{~m}$ wind speed in Nanjing was $1.5 \mathrm{~m} \mathrm{~s}^{-1}$ larger on 16-28 August 2013 than that on 16-28 August 2014 (Fig. 9). Also, the simulated $2 \mathrm{~m}$ temperature was $2.0 \mathrm{~K}$ higher on 16-28 August 2013 than that on 16-28 August 2014 (Fig. 9). Also, the simulated planetary boundary layer height (PBLH) was higher in August 2013, especially on 16-28 August, and it was $27.5 \mathrm{~m}$ higher than that on 16-28 August 2014 (Fig. 9). Larger wind speed and higher PBLH benefited the diffusion of air pollutants. Warming on the ground surface was conducive to the rise in convective instability and was also good for the vertical dilution and diffusion of pollutants. Thus, the diffusion conditions on 16-28 August 2013 were better than those on 1628 August 2014. Rather worse meteorological conditions on 16-28 August 2014 implied that abatement controls might play a more important role in improving air quality in YOG compared with the same period in 2013. Furthermore, relative humidity, cloud cover and shortwave solar radiation all affect ozone chemical reaction (Katragkou et al., 2011; Pu et al., 2017). The generation and photochemical reaction of surface ozone depends on the availability of solar radiation. During the heatwave period, lower relative humidity leads to less cloud cover, which could result in more net downward shortwave solar radiation and more production of $\mathrm{O}_{3}(\mathrm{Pu}$ et al., 2017). For ordinary $\mathrm{O}_{3}$, its production also corresponded well to the cloud cover. As shown in Fig. 9, more relative humidity resulted in more cloud cover in northern and eastern Nanjing during 16-28 August 2013, which resulted in less $\mathrm{O}_{3}$ in August 2013 but more $\mathrm{O}_{3}$ in August 2014 (Fig. 7).

\subsection{Simulated impact of emission reduction}

As for $\mathrm{SO}_{2}, \mathrm{NO}_{2}, \mathrm{PM}_{10}, \mathrm{PM}_{2.5}$ and $\mathrm{CO}$, the distributions of such short-lived chemical compositions are largely affected by their sources and sinks. As seen in Fig. 10, the simulated spatial distributions of concentration changes were uneven. Large variations were found in the west of Nanjing corresponding to the downwind regions of heavy reduction districts (see Fig. 2). Impact percentages (dspecies 
Table 5. Statistical analysis of hourly data in July-September 2014 at XL station (the unit is $\mu \mathrm{g} \mathrm{m}^{-3}$ except $\mathrm{CO}\left(\mathrm{mg} \mathrm{m}^{-3}\right)$ ). The change percentage of species $(\Delta a)$ in August 2014 based on July 2014. The change percentage of species $(\Delta b)$ in August 2014 is based on September 2014.

\begin{tabular}{|c|c|c|c|c|c|c|c|c|}
\hline Species & Month & Max & Min & Mean & Median & SD & $\Delta \mathrm{a}$ & $\Delta \mathrm{b}$ \\
\hline \multirow[t]{4}{*}{$\mathrm{SO}_{2}$} & July 2014 & 61.0 & 1.0 & 14.5 & 12.0 & 10.3 & & \\
\hline & August 2014 & 71.0 & 1.0 & 11.4 & 8.0 & 10.4 & $-21.2 \%$ & $-24.6 \%$ \\
\hline & September 2014 & 75.0 & 1.0 & 15.1 & 14.0 & 10.3 & & \\
\hline & July-September 2014 & 75.0 & 1.0 & 13.7 & 11.0 & 10.4 & & \\
\hline \multirow[t]{4}{*}{$\mathrm{NO}_{2}$} & July 2014 & 123.0 & 9.0 & 36.4 & 33.0 & 18.9 & $-15.8 \%$ & $-21.8 \%$ \\
\hline & August 2014 & 95.0 & 7.0 & 30.7 & 27.0 & 15.0 & & \\
\hline & September 2014 & 127.0 & 11.0 & 39.2 & 36.0 & 18.7 & & \\
\hline & July-September 2014 & 127.0 & 7.0 & 35.4 & 32.0 & 18.0 & & \\
\hline \multirow[t]{4}{*}{$\mathrm{PM}_{10}$} & July 2014 & 300.0 & 4.0 & 91.3 & 85.0 & 48.9 & & \\
\hline & August 2014 & 196.0 & 6.0 & 55.2 & 47.0 & 35.9 & $-39.6 \%$ & $-28.7 \%$ \\
\hline & September 2014 & 226.0 & 9.0 & 77.3 & 70.0 & 40.3 & & \\
\hline & July-September 2014 & 300.0 & 4.0 & 74.5 & 64.0 & 44.6 & & \\
\hline \multirow[t]{4}{*}{$\mathrm{PM}_{2.5}$} & July 2014 & 158.0 & 2.0 & 58.2 & 51.0 & 34.8 & & \\
\hline & August 2014 & 157.0 & 3.0 & 38.0 & 34.0 & 24.1 & $-34.6 \%$ & $-17.7 \%$ \\
\hline & September 2014 & 144.0 & 3.0 & 46.2 & 38.0 & 29.0 & & \\
\hline & July-September 2014 & 158.0 & 2.0 & 47.4 & 40.5 & 30.7 & & \\
\hline \multirow[t]{4}{*}{$\mathrm{CO}$} & July 2014 & 2.0 & 0.3 & 0.8 & 0.8 & 0.4 & & \\
\hline & August 2014 & 2.0 & 0.3 & 0.8 & 0.7 & 0.3 & $-7.1 \%$ & $-4.9 \%$ \\
\hline & September 2014 & 2.8 & 0.3 & 0.8 & 0.7 & 0.4 & & \\
\hline & July-September 2014 & 2.8 & 0.3 & 0.8 & 0.7 & 0.4 & & \\
\hline \multirow[t]{4}{*}{$\mathrm{O}_{3}$} & July 2014 & 238.0 & 2.0 & 78.4 & 67.0 & 55.6 & & \\
\hline & August 2014 & 148.0 & 2.0 & 38.7 & 32.0 & 28.3 & $-50.7 \%$ & $-39.9 \%$ \\
\hline & September 2014 & 226.0 & 2.0 & 64.4 & 54.0 & 46.4 & & \\
\hline & July-September 2014 & 238.0 & 2.0 & 60.3 & 48.0 & 47.7 & & \\
\hline
\end{tabular}

$(\%)=($ Experiment $1-$ Experiment 2$) /$ Experiment $2 \times 100 \%)$ of species were negative except $\mathrm{O}_{3}$, implying that regulatory efforts of emission were effective for the other species, but counterproductive to $\mathrm{O}_{3}$. Statistically, the concentrations of $\mathrm{SO}_{2}, \mathrm{NO}_{2}, \mathrm{PM}_{10}, \mathrm{PM}_{2.5}$ and $\mathrm{CO}$ in Nanjing were reduced by 24.6, 12.1, 15.1, 8.1 and 7.2\% during August 2014. As for $\mathrm{O}_{3}$, the variation was positive $(1.3 \%)$, especially in the downwind area of $\mathrm{NO}_{x}$ with heavy reduction, which might be due to the lower titration of $\mathrm{O}_{3}$ by $\mathrm{NO}_{x}$ (Liu et al., 2013; Dong et al., 2013). For primary and secondary particulate matter, the influence of emission reduction varied dramatically. As shown in Fig. 11, $\mathrm{PM}_{10 p}$ dropped by $39.6 \%$, while $\mathrm{PM}_{10 \text { s }}$ only declined by $2.9 \%$. $\mathrm{PM}_{2.5 \mathrm{p}}$ decreased by $26.2 \%$, while $\mathrm{PM}_{2.5 \mathrm{~s}}$ merely decreased by $2.9 \%$. It seems that emission controls had much more of an impact on primary pollutants, especially on coarse particulate matter.

\subsection{Comparison of simulated meteorological factors and emission reduction}

Figure 12 displays the simulated effect of meteorological factors and emission reduction in Nanjing on air quality improvement during August 2014. In general, meteorological conditions played a negative role in air quality promotion on most days and only played a positive role on a few days (see discussion in Sect. 3.2). On the other hand, emission reduction contributed to the decline of $\mathrm{SO}_{2}, \mathrm{NO}_{2}, \mathrm{PM}_{10}, \mathrm{PM}_{2.5}$, $\mathrm{CO}, \mathrm{PM}_{10 \mathrm{p}}, \mathrm{PM}_{10 \mathrm{~s}}, \mathrm{PM}_{2.5 \mathrm{p}}$ and $\mathrm{PM}_{2.5 \mathrm{~s}}$ at all times, especially for primary coarse particulate matter. However, reduction of $\mathrm{NO}_{x}$ could cause a slight rise in $\mathrm{O}_{3}$.

The opposite effects of meteorology and emission abatement on $\mathrm{SO}_{2}, \mathrm{NO}_{2}, \mathrm{PM}_{10}, \mathrm{PM}_{2.5}, \mathrm{CO}, \mathrm{PM}_{10 \mathrm{p}}, \mathrm{PM}_{10 \mathrm{~s}}, \mathrm{PM}_{2.5 \mathrm{p}}$ and $\mathrm{PM}_{2.5 \mathrm{~s}}$ during the whole month were significant as statistically listed in Table 6. CCM station represents the urban status, XL station represents the suburban status and NJ represents the whole city. Adverse meteorological conditions were found to raise the concentrations of the six pollutants to $17.4 \%$ for $\mathrm{SO}_{2}, 15.1 \%$ for $\mathrm{NO}_{2}, 15.6 \%$ for $\mathrm{PM}_{10}, 14.9 \%$ for $\mathrm{PM}_{2.5}, 6.4 \%$ for $\mathrm{CO}$ and $0.9 \%$ for $\mathrm{O}_{3}$ at CCM station, and $14.1 \%$ for $\mathrm{SO}_{2}, 12.4 \%$ for $\mathrm{NO}_{2}, 22.4 \%$ for $\mathrm{PM}_{10}, 24.5 \%$ for $\mathrm{PM}_{2.5}, 2.3 \%$ for $\mathrm{CO}$, and $1.6 \%$ for $\mathrm{O}_{3}$ at XL station. On the contrary, emission abatement reduced their levels in most cases, especially in the urban site. It seems that the levels of air pollutants were reduced more at CCM station compared to XL station. Emission abatement independently led to a 
(a) $\mathrm{dSO}_{2}(\%)$

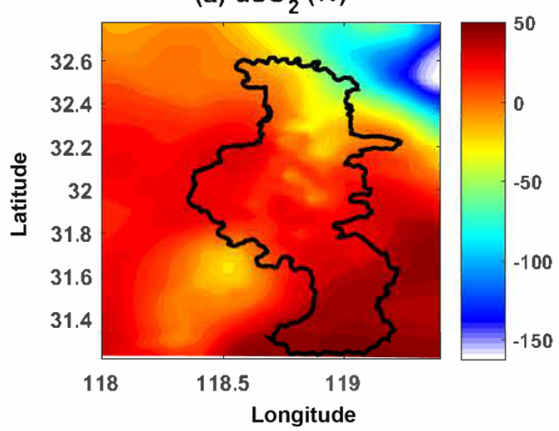

(d) $\mathrm{dPM}_{2.5}(\%)$

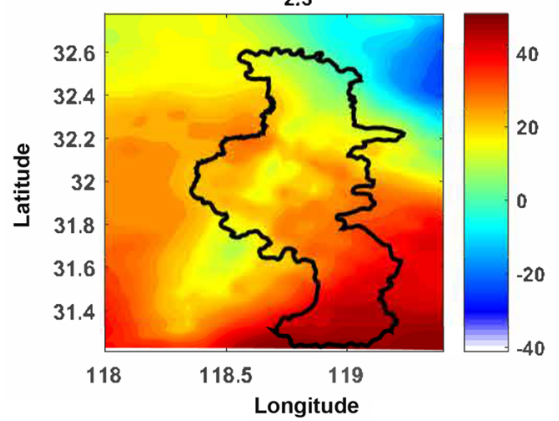

(b) $\mathrm{dNO}_{2}(\%)$

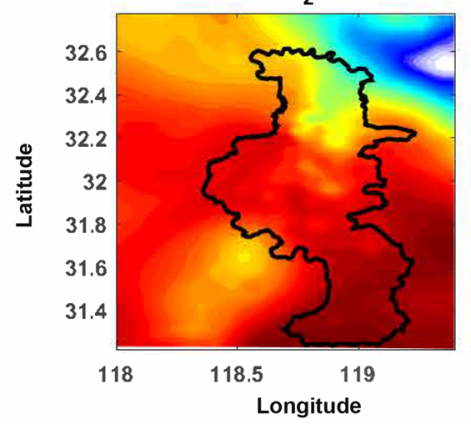

(e) dCO (\%)

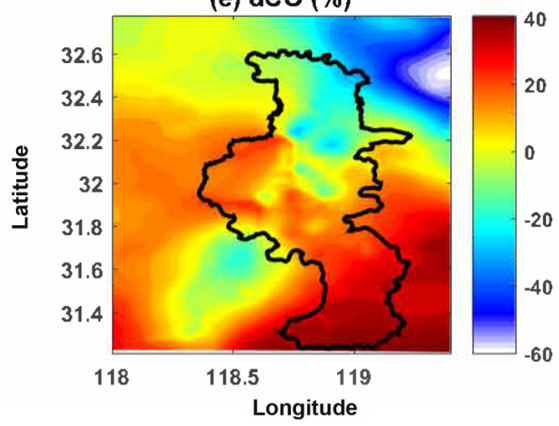

(c) $\mathrm{dPM}_{10}(\%)$

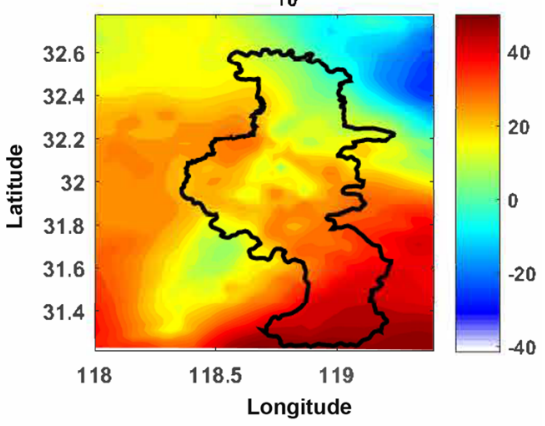

(f) $\mathrm{dO}_{3}(\%)$

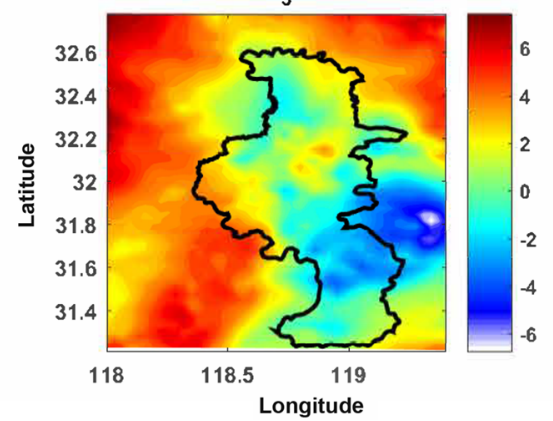

Figure 7. Influence of meteorology on hourly mean concentrations of air pollutants in August 2014 compared with August 2013. Black thick lines outline Nanjing. Panels (a-f) are hourly average values of impact percentage (dspecies $(\%)=($ Experiment $2-$ Experiment 3$) /$ Experiment $2 \times 100 \%)$ of $\mathrm{SO}_{2}, \mathrm{NO}_{2}, \mathrm{PM}_{10}, \mathrm{PM}_{2.5}, \mathrm{CO}$ and $\mathrm{O}_{3}$.

(a) $\mathrm{dPM}_{10 \mathrm{p}}(\%)$

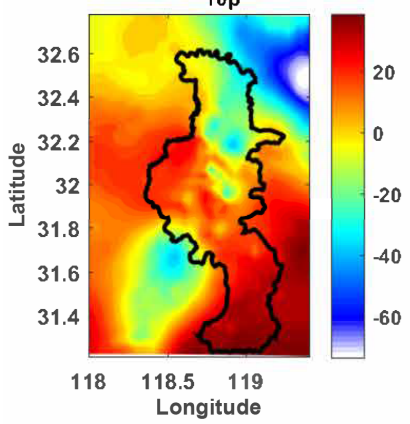

(b) $\mathrm{dPM}_{10 \mathrm{~s}}(\%)$

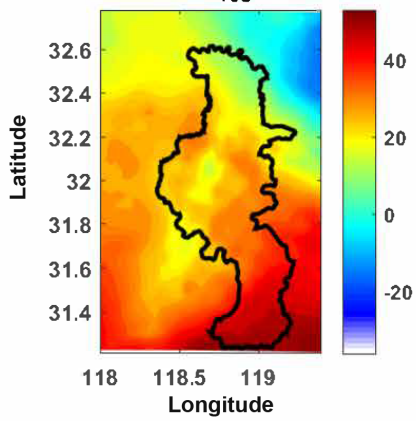

(c) $\mathrm{dPM}_{2.5 \mathrm{p}}(\%)$

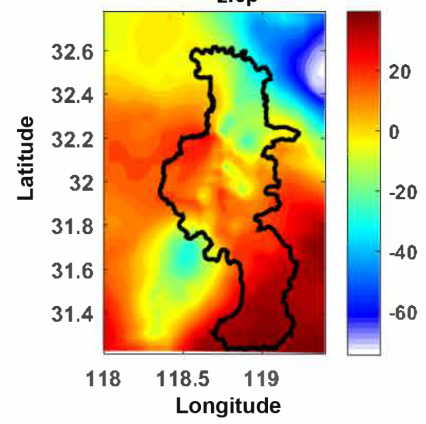

(d) $\mathrm{dPM}_{2.5 \mathrm{~s}}(\%)$

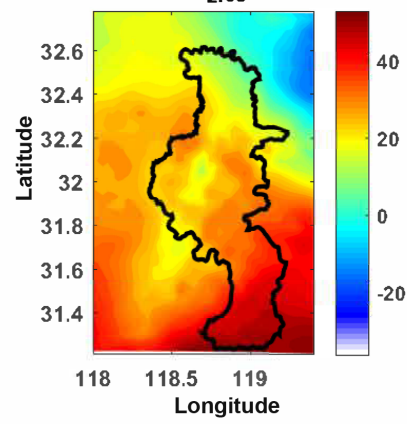

Figure 8. Influence of meteorology on hourly mean concentrations of primary and secondary particulate matter in August 2014 compared with August 2013. Black thick lines outline Nanjing. Panels (a-d) are hourly average values of impact percentage (dspecies $(\%)=($ Experiment $2-$ Experiment 3$) /$ Experiment $2 \times 100 \%)$ of $\mathrm{PM}_{10 \mathrm{p}}, \mathrm{PM}_{10 \mathrm{~s}}, \mathrm{PM}_{2.5 \mathrm{p}}$ and $\mathrm{PM}_{2.5 \mathrm{~s}}$.

$24.3 \%$ decrease in $\mathrm{SO}_{2}$ at $\mathrm{CCM}$ station, which was $5.1 \%$ higher compared to XL station. Moreover, the cutbacks of $\mathrm{NO}_{2}, \mathrm{PM}_{10}, \mathrm{PM}_{2.5}$ and $\mathrm{CO}$ were 11.7, 13.9, 7.5 and $7.0 \%$ at CCM station, being larger by 1.0 to $2.0 \%$ compared with $\mathrm{XL}$ station. Though $\mathrm{O}_{3}$ resulted in a slight rise under emission reduction scenarios ( 0.9 to $1.3 \%$ ) at both sites, the effectiveness of emission abatement was generally remarkable. As for primary and secondary particulate matter, meteorological factors also played a negative role during August 2014 and had slightly more effect on secondary fine particles. Emission controls seemed to cause tremendous impact on pri- mary particulate matter, especially for primary coarse particles. Emission abatement led to a $38.3 \%$ decrease in $\mathrm{PM}_{10 \mathrm{p}}$ at CCM station, a $33.2 \%$ decrease in $\mathrm{PM}_{10 \mathrm{p}}$ at $\mathrm{XL}$ station and a $39.6 \%$ decrease in $\mathrm{PM}_{10 \mathrm{p}}$ for the whole city. For secondary particulate matter, including sulfate, nitrate and ammonium salt, emission reduction played a rather minor role in cutting the pollution levels, with merely a $2.4 \%$ decrease in $\mathrm{PM}_{10 \mathrm{~s}}$ and $\mathrm{PM}_{2.5 \mathrm{~s}}$ at CCM station, a $2.9 \%$ decrease in $\mathrm{PM}_{10 \mathrm{~s}}$ and $\mathrm{PM}_{2.5 \mathrm{~s}}$ at XL station.

The decrease of $\mathrm{SO}_{2}$ might result from limiting and halting power plant emissions and improving coal combustion. 
(a) U10/V10

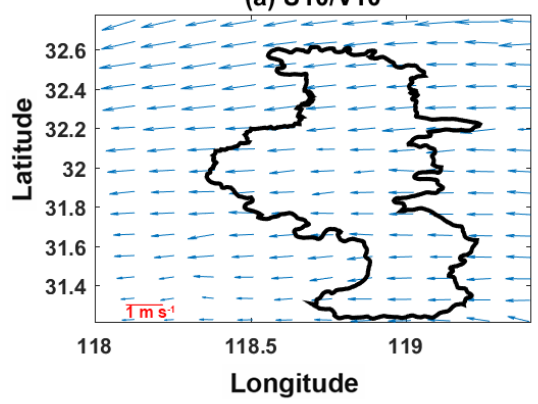

(d) RH2

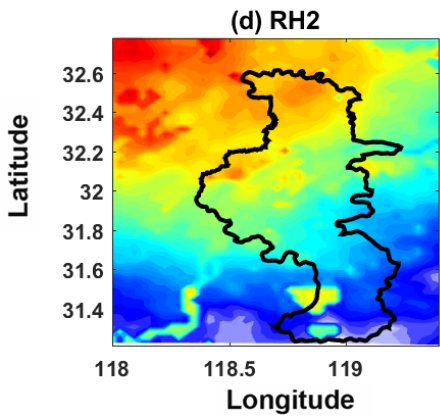

(b) T2

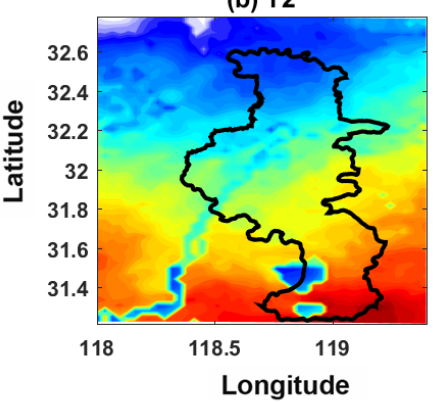

(c) PBLH

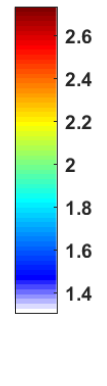

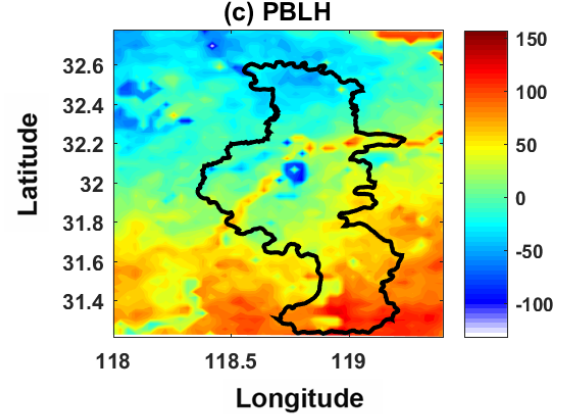

(e) CLDFRA
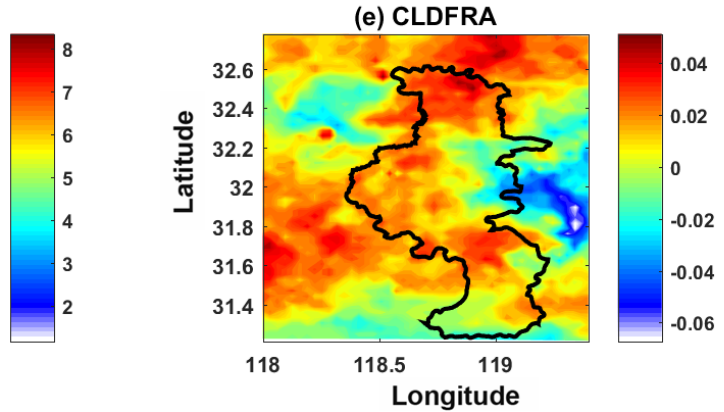

Figure 9. Bias of simulated hourly mean meteorological conditions during the YOG. Bias is meteorological factors on 16-28 August 2013 - meteorological factors on 16-28 August 2014. (a) Bias of wind at $10 \mathrm{~m}^{\text {during 16-28 August (m s}}{ }^{-1}$ ), (b) bias of temperature at $2 \mathrm{~m}$ during 16-28 August (K), (c) bias of planetary boundary layer height during 16-28 August (m), (d) bias of relative humidity at $2 \mathrm{~m}$ during 16-28 August (\%), (e) bias of cloud fraction during 16-28 August.

(a) $\mathrm{dSO}_{2}(\%)$

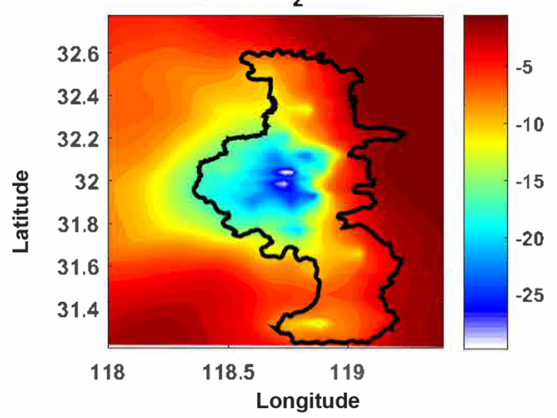

(d) $\mathrm{dPM}_{2.5}(\%)$
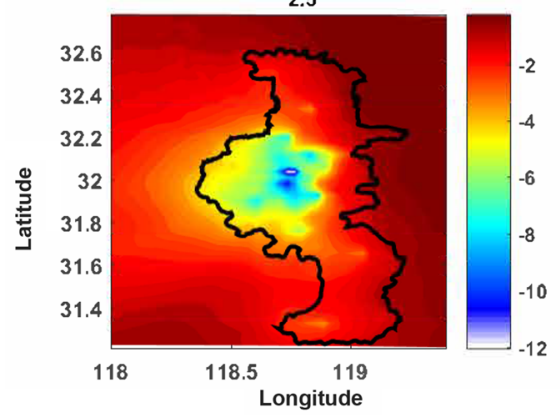

(b) $\mathrm{dNO}_{2}(\%)$

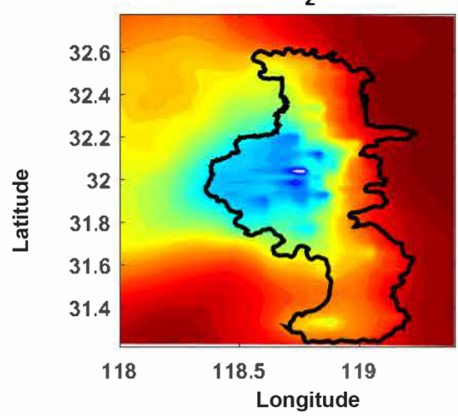

(e) dCO (\%)

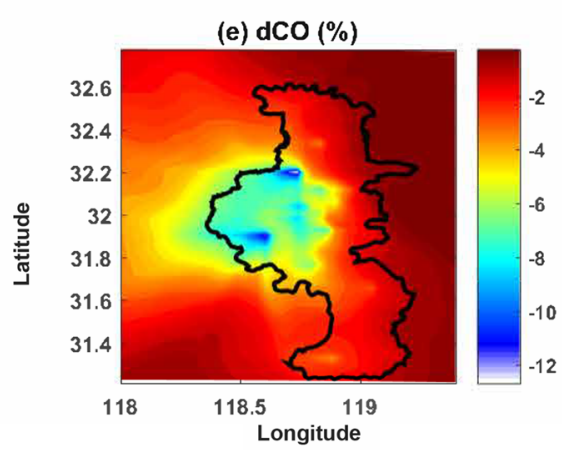

(c) $\mathrm{dPM}_{10}(\%)$

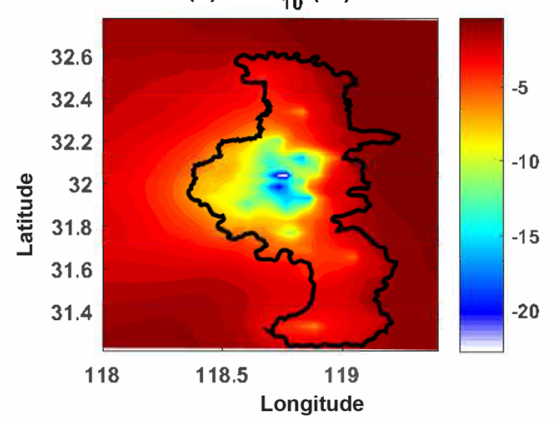

(f) $\mathrm{dO}_{3}(\%)$

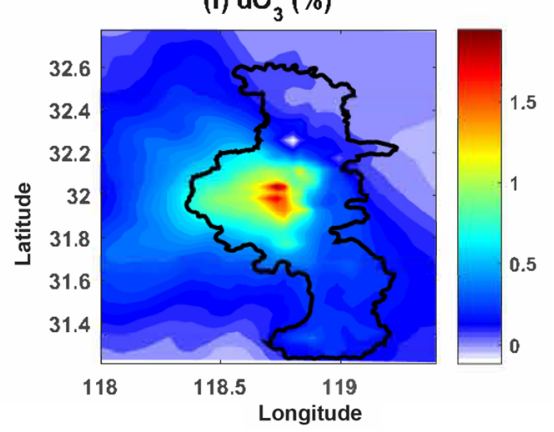

Figure 10. Influence of emission reduction on hourly mean concentrations of air pollutants in August 2014. Black thick lines draw the outline of Nanjing. Panels (a-f) are hourly average values of impact percentage (dspecies $(\%)=($ Experiment $1-$ Experiment 2$) /$ Experiment $2 \times 100 \%)$ of $\mathrm{SO}_{2}, \mathrm{NO}_{2}, \mathrm{PM}_{10}, \mathrm{PM}_{2.5}, \mathrm{CO}$ and $\mathrm{O}_{3}$. 

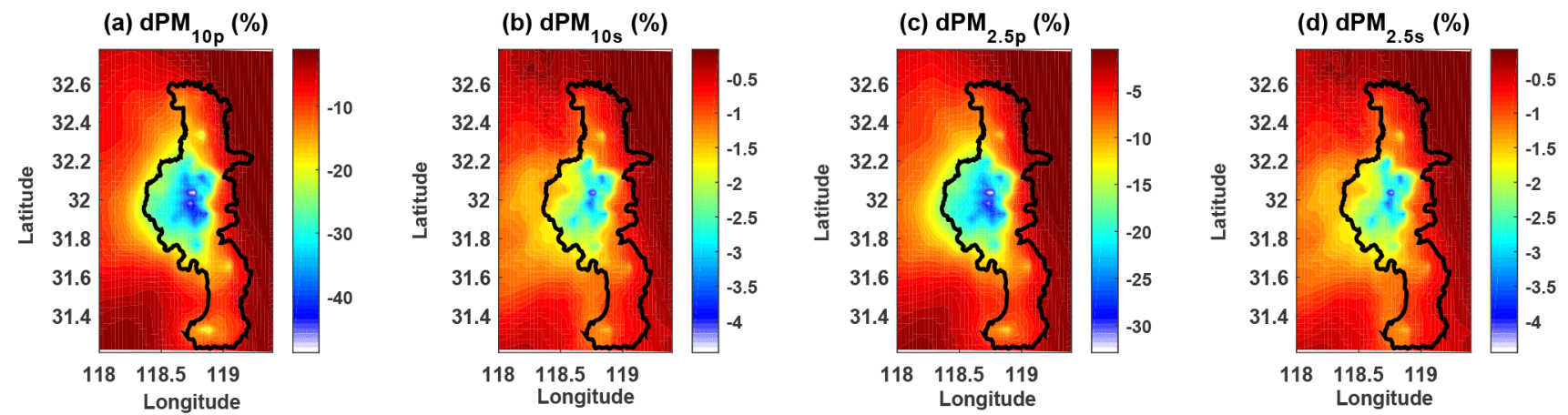

Figure 11. Influence of emission reduction on hourly mean concentrations of primary and secondary particulate matter in August 2014. Black thick lines draw the outline of Nanjing. Panels (a-d) are hourly average values of impact percentage (dspecies $(\%)=($ Experiment $1-$ Experiment 2$) /$ Experiment $2 \times 100 \%)$ of $\mathrm{PM}_{10 \mathrm{p}}, \mathrm{PM}_{10 \mathrm{~s}}, \mathrm{PM}_{2.5 \mathrm{p}}$ and $\mathrm{PM}_{2.5 \mathrm{~s}}$.
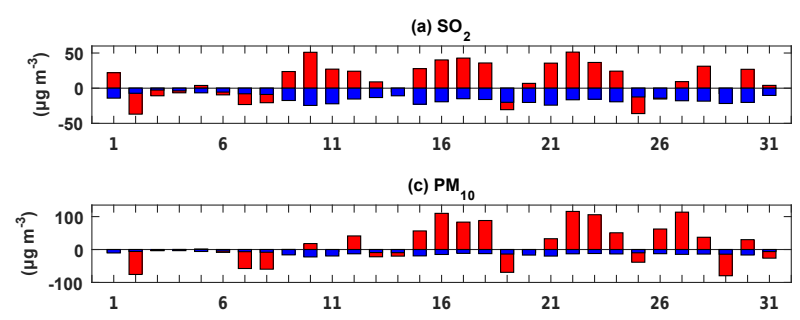

(e) $\mathrm{CO}$
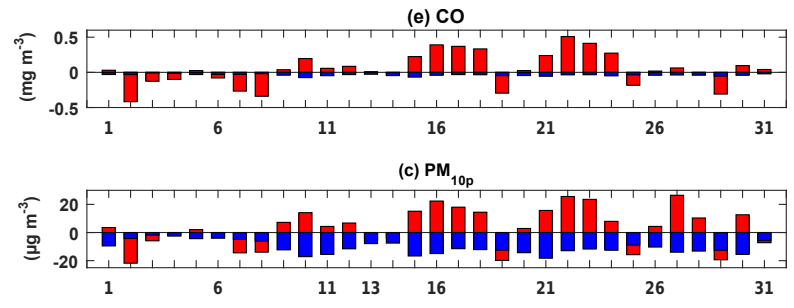

(d) $\mathrm{PM}_{2.5 \mathrm{p}}$

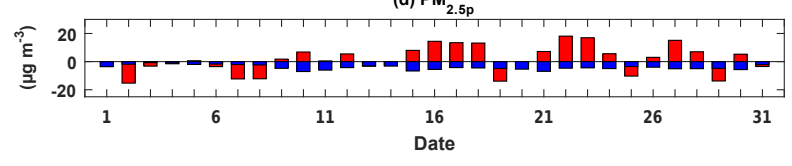

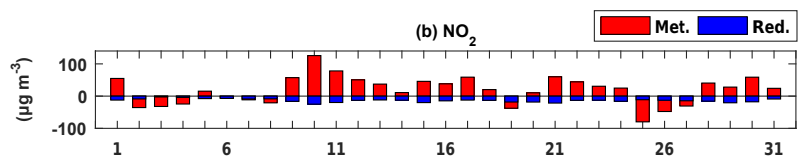
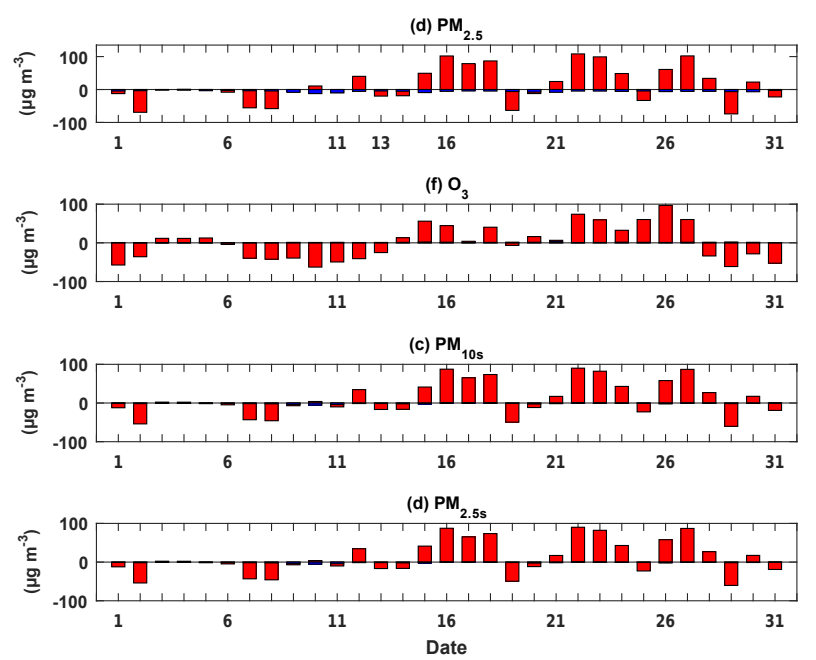

Figure 12. The simulated effect of meteorology and emission reduction on pollutant concentrations in Nanjing during 1-31 August 2014. Met. (Experiment 2-Experiment 3) represents the effect of meteorology while Red. (Experiment 1-Experiment 2) represents the simulated effect of emission reduction.

The prohibition of heavy pollution vehicles could contribute to a drop in $\mathrm{NO}_{2}$ and $\mathrm{CO}$. Also, limiting the production of industries helped to reduce $\mathrm{NO}_{2}$ and $\mathrm{CO}$. The decrease in particulate matter might be attributable to stopping construction processes and using coal with a low ash content for industry. For secondary particulate matter, controlling the emission of $\mathrm{SO}_{2}$ and $\mathrm{NO}_{x}$ could help to reduce the formation of sulfate and nitrate, but no control on the emission of $\mathrm{NH}_{3}$ could still result in a large amount of ammonium salt. The response of $\mathrm{O}_{3}$ to emission control could be due to its non-linear chemistry (Fu et al., 2012): reducing $\mathrm{NO}_{2}$ may have the side effect of increasing $\mathrm{O}_{3}$ because of the titration effect. On the whole, the meteorological factors and emission reduction during the
YOG had opposite effects on $\mathrm{SO}_{2}, \mathrm{NO}_{2}, \mathrm{PM}_{10}, \mathrm{PM}_{2.5}$ and $\mathrm{CO}$, and emission reduction indeed played a very important role in air quality improvement.

\section{Summary and conclusions}

The air quality during the 2nd YOG was superior according to the current NAAQS. Both observation and modelling confirmed that stringent emission reductions had an effect on ambient air quality improvement during the Youth Olympic Games, especially on $\mathrm{SO}_{2}, \mathrm{NO}_{2}, \mathrm{PM}_{10}, \mathrm{PM}_{2.5}$ and CO. Compared to August 2013, the observed concentrations in August 2014 dropped by $64.7 \%$ for $\mathrm{SO}_{2}, 29.8 \%$ for $\mathrm{PM}_{10}, 9.8 \%$ for 
Table 6. Comparison between the simulated effect of meteorology and emission reduction at CCM and XL stations. Met. is the change percentage of species in Experiment 2 based on Experiment 3, representing the effect of meteorology. Red. is the change percentage of species in Experiment 1 based on Experiment 2, representing the effect of Nanjing local emission reduction.

\begin{tabular}{lrrrrrr}
\hline Species & $\begin{array}{r}\text { Met. } \\
(\mathrm{CCM})\end{array}$ & $\begin{array}{r}\text { Red. } \\
(\mathrm{CCM})\end{array}$ & $\begin{array}{r}\text { Met. } \\
(\mathrm{XL})\end{array}$ & $\begin{array}{r}\text { Red. } \\
(\mathrm{XL})\end{array}$ & $\begin{array}{r}\text { Met. } \\
(\mathrm{NJ})\end{array}$ & $\begin{array}{r}\text { Red. } \\
(\mathrm{NJ})\end{array}$ \\
\hline $\mathrm{SO}_{2}$ & $17.4 \%$ & $-24.3 \%$ & $14.1 \%$ & $-19.2 \%$ & $17.5 \%$ & $-24.6 \%$ \\
$\mathrm{NO}_{2}$ & $15.1 \%$ & $-11.7 \%$ & $12.4 \%$ & $-10.2 \%$ & $16.9 \%$ & $-12.1 \%$ \\
$\mathrm{PM}_{10}$ & $15.6 \%$ & $-13.9 \%$ & $22.4 \%$ & $-11.9 \%$ & $18.5 \%$ & $-15.1 \%$ \\
$\mathrm{PM}_{2.5}$ & $14.9 \%$ & $-7.5 \%$ & $24.5 \%$ & $-6.3 \%$ & $18.8 \%$ & $-8.1 \%$ \\
$\mathrm{CO}$ & $6.4 \%$ & $-7.0 \%$ & $2.3 \%$ & $-5.5 \%$ & $7.8 \%$ & $-7.2 \%$ \\
$\mathrm{O}_{3}$ & $0.9 \%$ & $1.3 \%$ & $1.6 \%$ & $0.9 \%$ & $0.7 \%$ & $1.5 \%$ \\
$\mathrm{PM}_{10 \mathrm{p}}$ & $13.2 \%$ & $-38.3 \%$ & $5.9 \%$ & $-33.2 \%$ & $12.6 \%$ & $-39.6 \%$ \\
$\mathrm{PM}_{10 \mathrm{~s}}$ & $16.7 \%$ & $-2.4 \%$ & $29.4 \%$ & $-2.9 \%$ & $21.5 \%$ & $-2.9 \%$ \\
$\mathrm{PM}_{2.5 \mathrm{p}}$ & $8.4 \%$ & $-25.8 \%$ & $4.9 \%$ & $-20.1 \%$ & $9.5 \%$ & $-26.2 \%$ \\
$\mathrm{PM}_{2.5 \mathrm{~s}}$ & $16.7 \%$ & $-2.4 \%$ & $29.4 \%$ & $-2.9 \%$ & $21.5 \%$ & $-2.9 \%$ \\
\hline
\end{tabular}

$\mathrm{PM}_{2.5}, 8.9 \%$ for $\mathrm{CO}$ and $31.7 \%$ for $\mathrm{O}_{3}$ at $\mathrm{CCM}$ station, and by $50.0 \%$ for $\mathrm{SO}_{2}, 18.6 \%$ for $\mathrm{NO}_{2}, 32.8 \%$ for $\mathrm{PM}_{10}, 4.1 \%$ for $\mathrm{PM}_{2.5}$ and $31.7 \%$ for $\mathrm{O}_{3}$ at XL station. The simulated impact percentages of emission reductions were $-24.6,-12.1$, $-15.1,-8.1$ and $-7.2 \%$ for $\mathrm{SO}_{2}, \mathrm{NO}_{2}, \mathrm{PM}_{10}, \mathrm{PM}_{2.5}$ and CO.

The meteorological conditions during the YOG were inferior to those of the same period in 2013, with lower temperature and weaker winds. Model simulations show that unfavourable weather conditions caused higher concentrations for all species including $\mathrm{O}_{3}$, which increased due to less cloud cover. In addition, meteorological conditions had a slightly greater effect on secondary fine particulate matter compared to primary fine particulate matter. Emission reduction could reduce the levels of $\mathrm{SO}_{2}, \mathrm{NO}_{2}, \mathrm{CO}$ and particulate matter, especially for primary coarse particles. Thus, emission reduction is important for air quality improvement during the YOG.

In general, air quality during the YOG benefits a lot from emission reduction. A good example has been set for air quality protection for important social events. However, the enhanced concentrations of air pollutants after the YOG (in September 2014) suggest that short-term emission control can only ease air pollution effectively and temporarily. Longterm control policies are necessary to ensure pleasant air quality in future.

Data availability. The air quality monitoring records are available at http://222.190.111.117:8023/. The Multi-resolution Emission Inventory for China (MEIC) is available at http://www.meicmodel. org/dataset-meic.html. The WRF model is available at http://www2. mmm.ucar.edu/wrf/users/downloads.html. The CMAQ model is available at https://www.epa.gov/cmaq/download-cmaq.

Competing interests. The authors declare that they have no conflict of interest.
Disclaimer. The contents of this paper are solely the responsibility of the authors and do not necessarily represent the official views of sponsors.

Special issue statement. This article is part of the special issue "Regional transport and transformation of air pollution in eastern China”. It is not associated with a conference.

Acknowledgements. This work was supported by the National Natural Science Foundation of China (41575145, 41621005, 91544230), the National Key Research Development Programme of China (2016YFC0203303, 2016YFC0208504, 2014CB441203), the National Special Fund for the Weather Industry (GYHY201206011) and the National Special Fund for the Environmental Protection Industry (GYHY201409008). We are grateful to Yu Zhao from the School of Environment of Nanjing University for supplying the emission data for Nanjing. We are also grateful to the MEIC group from Tsinghua University for supplying the multiresolution emission inventory for China.

Edited by: Tong Zhu

Reviewed by: three anonymous referees

\section{References}

Binkowski, F. S. and Roselle, S. J.: Models-3 Community Multiscale Air Quality (CMAQ) model aerosol component 1. Model description, J. Geophys. Res., 108, 4183, https://doi.org/10.1029/2001JD001409, 2003.

Byun, D. and Schere, K. L.: Review of the governing equations, computational algorithms, and other components of the models3 Community Multiscale Air Quality (CMAQ) modeling system, Appl. Mech. Rev., 59, 51-77, https://doi.org/10.1115/1.2128636, 2006.

Cai, H. and Xie, S.: Traffic-related air pollution modeling during the 2008 Beijing Olympic Games: the effects of an odd-even day 
traffic restriction scheme, Sci. Total Environ., 409, 1935-1948, https://doi.org/10.1016/j.scitotenv.2011.01.025, 2011.

Cermak, J. and Knutti, R.: Beijing Olympics as an aerosol field experiment, Geophys. Res. Lett., 36, 1-5, https://doi.org/10.1029/2009GL038572, 2009.

Chen P., Wang T., and $\mathrm{Hu}$ X.: Chemical Mass Balance Source Apportionment of Size-Fractionated Particulate Matter in Nanjing, China, Aerosol Air Qual. Res., 15, 1855-1867, https://doi.org/10.4209/aaqr.2015.03.0172, 2015.

Chen, P., Wang, T., Lu, X., Yu, Y., Kasoar, M., Xie, M., and Zhuang, B.: Source apportionment of size-fractionated particles during the 2013 Asian Youth Games and the 2014 Youth Olympic Games in Nanjing, China, Sci. Total Environ., 579, 860-870, https://doi.org/10.1016/j.scitotenv.2016.11.014, 2017.

Ding, J., van der A, R. J., Mijling, B., Levelt, P. F., and Hao, N.: $\mathrm{NO}_{x}$ emission estimates during the 2014 Youth Olympic Games in Nanjing, Atmos. Chem. Phys., 15, 9399-9412, https://doi.org/10.5194/acp-15-9399-2015, 2015.

Dong, X. Y., Gao, Y., Fu, J. S., Li, J., Huang, K., Zhuang, G. S., and Zhou, Y.: Probe into gaseous pollution and assessment of air quality benefit under sector dependent emission control strategies over megacities in Yangtze River Delta, China, Atmos. Environ., 79, 841-852, https://doi.org/10.1016/j.atmosenv.2013.07.041, 2013.

Foley, K. M., Roselle, S. J., Appel, K. W., Bhave, P. V., Pleim, J. E., Otte, T. L., Mathur, R., Sarwar, G., Young, J. O., Gilliam, R. C., Nolte, C. G., Kelly, J. T., Gilliland, A. B., and Bash, J. O.: Incremental testing of the Community Multiscale Air Quality (CMAQ) modeling system version 4.7, Geosci. Model Dev., 3, 205-226, https://doi.org/10.5194/gmd-3-205-2010, 2010.

Fu, J. S., Dong, X. Y., Gao, Y., Wong, D. C., and Lam, Y. F.: Sensitivity and linearity analysis of ozone in East Asia: the effects of domestic emission and intercontinental transport, J. Air Waste Manage., 62, 1102-1114, https://doi.org/10.1080/10962247.2012.699014, 2012.

Hao, N., Valks, P., Loyola, D., Cheng, Y. F., and Zimmer, W.: Space-based measurements of air quality during the World Expo 2010 in Shanghai, Environ. Res. Lett., 6, 044004, https://doi.org/10.1088/1748-9326/6/4/044004, 2011.

Jiang, F., Wang, T. J., Wang, T. T., Xie, M., and Zhao, H.: Numerical modeling of a continuous photochemical pollution episode in Hong Kong using WRF-chem, Atmos. Environ., 42, 8717-8727, https://doi.org/10.1016/j.atmosenv.2008.08.034, 2008.

Jiang, F., Zhou, P., Liu, Q., Wang, T. J., Zhuang, B. L., and Wang, X. Y.: Modeling tropospheric ozone formation over East China in springtime, J. Atmos. Chem., 69, 303-319, https://doi.org/10.1007/s10874-012-9244-3, 2012.

Katragkou E., Zanis P., Kioutsioukis I., Tegoulias I., Melas D., Krüger, B. C., and Coppola E.: Future climate change impacts on summer surface ozone from regional climate-air quality simulations over Europe, J. Geophys. Res.-Atmos., 116, D22307, https://doi.org/10.1029/2011JD015899, 2011.

Li, M. M., Song, Y., Mao, Z. C., Liu, M. X., and Huang, X.: Impacts of thermal circulations induced by urbanization on ozone formation in the Pearl River Delta region, China, Atmos. Environ., 127, 382-392, https://doi.org/10.1016/j.atmosenv.2015.10.075, 2016.

Liao, J. B., Wang, T. J., Wang, X. M., Xie, M., Jiang, Z. Q., Huang, X. X., and Zhu, J. L.: Impacts of different urban canopy schemes in WRF/Chem on regional climate and air quality in Yangtze River Delta, China, Atmos. Res., 145, 226-243, https://doi.org/10.1016/j.atmosres.2014.04.005, 2014.

Liao, J. B., Wang, T. J., Jiang, Z. Q., Zhuang, B. L., Xie, M., Yin, C. Q., Wang, X. M., Zhu, J. L., Fu, Y., and Zhang, Y.: WRF/Chem modeling of the impacts of urban expansion on regional climate and air pollutants in Yangtze River Delta, China, Atmos. Environ., 106, 204-214, https://doi.org/10.1016/j.atmosenv.2015.01.059, 2015.

Lin Y., Huang, K., Zhuang, G., Fu, J. S., Xu, C., Shen, J., and Chen, S.: Air Quality over the Yangtze River Delta during the 2010 Shanghai Expo, Aerosol Air Qual. Res., 13, 1655-1666, https://doi.org/10.4209/aaqr.2012.11.0312, 2013.

Liu, H., Wang, X. M., Zhang, J. P., He, K. B., Wu, Y., and $\mathrm{Xu}$, J. Y.: Emission controls and changes in air quality in Guangzhou during the Asian Games, Atmos. Environ., 76, 8193, https://doi.org/10.1016/j.atmosenv.2012.08.004, 2013.

Okuda, T., Matsuura, S., Yamaguchi, D., Umemura, T., Hanada, E., Orihara, H., Tanaka, S., He, K. B., Ma, Y. L., Cheng, Y., and Liang, L. L.: The impact of the pollution control measures for the 2008 Beijing Olympic Games on the chemical composition of aerosols, Atmos. Environ., 45, 2789-2794, https://doi.org/10.1016/j.atmosenv.2011.01.053, 2011.

Pu, X., Wang, T. J., Huang, X., Melas, D., Zanis, P., Papanastasiou, D. K., and Poupkou, A.: Enhanced surface ozone during the heat wave of 2013 in Yangtze River Delta region, China, Sci. Total Environ., 603-604, 807-816, https://doi.org/10.1016/j.scitotenv.2017.03.056, 2017.

Shu, L., Xie, M., Wang, T., Gao, D., Chen, P., Han, Y., Li, S., Zhuang, B., and Li, M.: Integrated studies of a regional ozone pollution synthetically affected by subtropical high and typhoon system in the Yangtze River Delta region, China, Atmos. Chem. Phys., 16, 15801-15819, https://doi.org/10.5194/acp-16-158012016, 2016.

Skamarock, W. C., Klemp, J. B., Dudhia, J., Gill, D. O., Barker, D. M., Duda, M. G., Huang, X. Y., Wang, W., and Powers, J. G.: A Description of the Advanced Research WRF Version 3, NCAR Tech Notes-475+STR, available at: http://opensky.ucar. edu/islandora/object/technotes:500 (last access: 5 November 2017), 2008.

State Environmental Protection Administration of China: China National Environmental Protection Standard: Automated Methods for Ambient Air Quality Monitoring, China Environmental Science Press, Beijing, China, 2006.

Streets, D. G., Fu, J. S., Jang, C. J., Hao, J. M., He, K. B., Tang, X. Y., Zhang, Y. H., Wang, Z. F., Li, Z. P., Zhang, Q., Wang, L. T., Wang, B. Y., and Yu, C.: Air quality during the 2008 Beijing Olympic Games, Atmos. Environ., 41, 480-492, https://doi.org/10.1016/j.atmosenv.2006.08.046, 2007.

Wang, T., Nie, W., Gao, J., Xue, L. K., Gao, X. M., Wang, X. F., Qiu, J., Poon, C. N., Meinardi, S., Blake, D., Wang, S. L., Ding, A. J., Chai, F. H., Zhang, Q. Z., and Wang, W. X.: Air quality during the 2008 Beijing Olympics: secondary pollutants and regional impact, Atmos. Chem. Phys., 10, 7603-7615, https://doi.org/10.5194/acp-10-7603-2010, 2010.

Wang, W. T., Primbs, T., Tao, S., Zhu, T., and Simonich, S. L.: Atmospheric particulate matter pollution during the 2008 Beijing Olympics, Environ. Sci. Technol., 43, 5314-5320, 2009.

Wang, X., Westerdahl, D., Chen, L. C., Wu, Y., Hao, J. M., Pan, X. C., Guo, X. B., and Zhang, K. M.: Evaluating the air quality im- 
pacts of the 2008 Beijing Olympic Games: On-road emission factors and black carbon profiles, Atmos. Environ. 43, 4535-4543, https://doi.org/10.1016/j.atmosenv.2009.06.054, 2009.

Xie, M., Zhu, K. G., Wang, T. J., Yang, H. M., Zhuang, B. L., Li, S., Li, M. G., Zhu, X. S., and Ouyang, Y.: Application of photochemical indicators to evaluate ozone nonlinear chemistry and pollution control countermeasure in China, Atmos. Environ., 99, 466-473, https://doi.org/10.1016/j.atmosenv.2014.10.013, 2014.

Xie, M., Liao, J., Wang, T., Zhu, K., Zhuang, B., Han, Y., Li, M., and Li, S.: Modeling of the anthropogenic heat flux and its effect on regional meteorology and air quality over the Yangtze River Delta region, China, Atmos. Chem. Phys., 16, 6071-6089, https://doi.org/10.5194/acp-16-6071-2016, 2016.

Xing, J., Zhang, Y., Wang, S. X., Liu, X. H., Cheng, S. H., Zhang, Q., Chen, Y. S., Streets, D. G., Jang, G., Hao, J. M., and Wang, W. X.: Modeling study on the air quality impacts from emission reductions and atypical meteorological conditions during the 2008 Beijing Olympics, Atmos. Environ., 45, 1786-1798, https://doi.org/10.1016/j.atmosenv.2011.01.025, 2011.

Xu, H. M., Tao, J., Ho, S. S. H., Ho, K. F., Cao, J. J., Li, N., Chow, J. C., Wang, G. H., Han, Y. M., Zhang, R. J., Watson, J. G., and Zhang, J. Q.: Characteristics of fine particulate non-polar organic compounds in Guangzhou during the 16th Asian Games: Effectiveness of air pollution controls, Atmos. Environ., 76, 94-101, https://doi.org/10.1016/j.atmosenv.2012.12.037, 2013.
Yarwood, G., Rao, S., Yocke, M., and Whitten G.: Updates to the Carbon Bond chemical mechanism: CB05, Final Report to the US EPA, RT-0400675, available at: https://www.researchgate. net/publication/284553449_Updates_to_the_carbon_bond_ chemical_mechanism_CB05_final_report_to_the_US_EPA (last access: 5 November 2017), 2005.

Zhou, D., Li, B., Huang, X., Virkkula, A., Wu, H., Zhao, Q., Zhang, J., Liu, Q., Li, L., Li, C., Chen, F., Yuan, S., Qiao, Y., Shen, G., and Ding, A.: The Impacts of Emission Control and Regional Transport on $\mathrm{PM}_{2.5}$ Ions and Carbon Components in Nanjing during the 2014 Nanjing Youth Olympic Games, Aerosol Air Qual. Res., 17, 730-740, https://doi.org/10.4209/aaqr.2016.03.0131, 2017.

Zhou, Y., Wu, W., Yang, L., Fu, L. X., He, K. B., Wang, S. X., Hao, J. M., Chen, J. C., and Li, C. Y.: The impact of transportation control measures on emission reductions during the 2008 Olympic Games in Beijing, China, Atmos. Environ., 44, 285293, https://doi.org/10.1016/j.atmosenv.2009.10.040, 2010. 